\title{
Heterogeneous Parameter Uncertainty and the Timing of Investment during Crisis
}

\author{
Shawn Ni and Ronald A. Ratti \\ University of Missouri \\ University of Western Sydney
}

\begin{abstract}
We present a model in which investors observe the same macroeconomic data but have varying levels of information about the parameters that determine the distribution of the expected returns on investment. During a crisis that increases macroeconomic uncertainty and reduces asset prices, the threshold required return that triggers investment is lower for an informed investor than for an uninformed investor. Simulation of the model suggests that when macroeconomic uncertainty is high investment may increase, is mostly by informed investors, and as time goes on is progressively more by investors who were initially relatively uninformed about model parameters. For over 10,000 instances of firm-level FDI data for Korea from 1996 to 2001, regression results are consistent with the hypothesis that disproportionably more FDI is made by more informed investors during a period of high macroeconomic uncertainty.
\end{abstract}

JEL: D8, E2, F4

Keywords: Parameter uncertainty; investor information; option value; Bayesian updating; FDI

\section{Correspondence}

Shawn Ni, Department of Economics, University of Missouri, Columbia, MO 65211, USA, telephone: 573-882-6878, e-mail: NiX@missouri.edu;

Ronald A. Ratti, e-mail: r.ratti@uws.edu.au

The authors have benefited from discussions with James Anderson, Alan Deardorff, Michael Hoffman, Stephen Miller, and Vitor Trindade. 


\section{Introduction}

In the famous 'option value of waiting under uncertainty' investment models of McDonald and Siegel (1986), Dixit (1989), and Dixit and Pindyck (1994), investors have perfect information on the parameters in the model that generates signals. In recent papers Gryglewicz et al. (2008) shows that for projects with finite life investment may be accelerated by increased uncertainty, Gutierrez (2007) shows that uncertainty can increase investment if projects devalue over time, and Wong (2007) reports that for "relatively safe" projects increased uncertainty may reduce the exercise time. ${ }^{1}$ In this paper we present a model in which investors are uncertain about the parameters that determine the distribution of the returns on investment, and in which an investor's threshold of return that triggers investment depends on uncertainty about these parameters. Investors will be assumed to observe the same macroeconomic data but will differ in terms of their assessment about the impact of the state of the economy on the return to their individual project. The study is motivated by the observation that during the Asian financial crisis inward FDI to Korea increased substantially, driven disproportionately by foreign investors with better information revealed by prior experience and by larger size of investment. Thus, during a period of increased uncertainty and opportunity, investors more likely to have relatively better information about model parameters acted with the most opportune timing.

In our model, the option value of waiting depends on subjective uncertainty (i.e., the uncertainty about the parameters that determine the distribution of the draws) as well as on objective uncertainty (the luck of the draws from the model given the parameters). ${ }^{2}$ We model a situation in which an increase in macroeconomic uncertainty influences uncertainty about both the mean and the variance of the distribution of individual project returns. Investors are assumed to have heterogeneous information about the parameters shaping project returns and to update their information from observations of signals on returns. Investor response to macroeconomic uncertainty on whether to invest is shown to depend on the level of information an investor has about the data generating model. An implication of the model is that if subjective uncertainties are time varying across investors, then there need not exist a stable empirical relationship in the aggregate response of investors to changes in macroeconomic variables.

Simulation of the model suggests that in a state characterized by greater uncertainty and higher potential expected return investment may increase and is mostly by informed investors, and that as time goes on investment is progressively more by investors who

\footnotetext{
1 Other papers have considered multiple sources of uncertainty within the context of irreversible and partially irreversible models of investment. Bertola and Caballero (1994) show that for irreversible investment the required return is higher when the price of new capital is more volatile. In the partially irreversible investment model presented in Bloom et al (2007) in which firm-level investment response to policy and demand shocks is more cautious during periods of high uncertainty.

2 Bayesian learning has been applied in macroeconomic models in a number of contexts. Jovanovic (1979) and Prescott and Townsend (1980) provide theoretical analysis of labor market equilibrium when workers' productivity is learned over time through Bayesian updating. In an infinite period optimal control setting, Easley and Kiefer (1988) and Wieland (2000) show how policy makers should conduct experiment to draw inference about the parameters in the economy through Bayesian learning in the process of maximizing the posterior expectation of an objective function.
} 
were initially relatively uncertain about model parameters. ${ }^{3}$ Bayesian updating of subjective uncertainty is not a new concept, neither is the notion that time-varying objective uncertainty affects optional value of an investment. But the empirical implications of the theory in the present paper, that investors' subjective uncertainty influences the timing of investment, are rarely tested, mainly because of lack of good proxies of investors' subjective uncertainty on investment projects. Our empirical test of the theory is based on firm level FDI data where an investing firm's subjective uncertainty can be proxied by investor history and size of FDI. Macroeconomic uncertainty is proxied by substantial movement and volatility in the exchange rate that is observed by all investors. Our test shows that investor information plays a prominent role in FDI decision in a time of increased uncertainty.

The literature on FDI and the exchange rate has not considered the effect of investor uncertainty about model parameters on the relationship between the decision to invest and macroeconomic factors such as the exchange rate and exchange rate volatility. ${ }^{4}$ The emphasis in the literature is to examine the relationship between FDI and the exchange rate for given firm-specific characteristics. In influential papers Froot and Stein (1991) and Blonigen (1997) consider the effect of financial restrictions on domestic firms and differential value of firm-specific assets on the effect of devaluation on FDI. The effect of increased uncertainty about the exchange rate on FDI has considered risk-averse firms making investment decisions prior to the resolution of uncertainty, as in Cushman (1985) and Goldberg and Kolstad (1995), and has been based on options theory, as in Campa (1993), with a rise in uncertainty causing a delay in FDI.

Our study adds to the literature on why foreign-owned firms would attract foreign direct investment during financial crisis. Aguiar and Gopinath (2005) examine 6000 cases of merger and acquisitions between 1986 and 2001 (with roughly one third of the cases involving a foreign investor) in five East Asian countries including Korea. They find that in a linear probability regression model, the probability that a firm is acquired by a foreign investor rather than a domestic investor in 1998 is negatively correlated with firm's cashflow. This is consistent with the notion that FDI after the financial crisis is driven by the hosts' need for liquidity which is undoubtedly is an important part of the explanation for the pattern of FDI during crisis. Our study uses data set of all Korean FDI cases. Unlike merger and acquisitions, FDIs between the same pair of host and investor firms may occur repeatedly. We argue that the timing and the size of FDIs made by different investors contains crucial information on the motives for FDI.

\footnotetext{
3 Some extensions of Dixit and Pindyck (1994) obtain the outcome that increases in uncertainty will increase investment. For example, Abel et al. (1996) options model of partially irreversible investment generates the result that given a potentially favorable resale price of capital, an increase in investment might be generated by a rise in uncertainty.

${ }^{4}$ A wealth of theories and empirical tests has been developed on how Foreign Direct Investment (FDI) responds to changes in macroeconomic variables. Blonigen (2005) surveys empirical work on FDI determinants and emphasizes the need for more firm-level empirical analysis of hypotheses. The main insight from industrial organization regarding FDI is that it increases at the level of the firm the value of domestic assets, through better foreign management expertise, better monitoring of the management, and easier adoption of technology. Caves (1971) surveys and assesses these arguments. Lipsey (2000) notes that inward and outward FDI tend to move together, suggesting that that the primary function of FDI is allowing for efficient foreign owners to gain control of domestic companies rather than financing capital formation.
} 
Building on Kindleberger's (1969) suggestion that analysis of FDI focus on the issue of why an asset might be more valuable under foreign control than domestic control, Krugman (1998) argues that there are two types of foreign investor during crisis and the type reveals the underlying cause or nature of crisis. Domestic firms after a crisis caused by moral hazard will be taken over by foreign investors more competent than the previous domestic owners; and after a crisis caused by panic domestic firms will tend to end up with foreign owners who have more liquidity than domestic owners rather than more expertise than domestic owners. We argue that the liquidity explanation is consistent with new FDIs from inexperienced foreign investors. During the Korean financial crisis we find that the main contribution of foreign direct investment is by experienced multinational firms making additional investments to the same host firms. Razin and Sadka (2003) emphasize the motivation of gaining information for FDI investors. They theorize that foreign companies are better at evaluating the prospects of domestic firms (proxied by firm-specific productivity parameters) and become 'insiders' of high productivity firms. ${ }^{5}$

While providing liquidity to host firms is a motive for the surge of FDI cases during crisis, the difference in the timing of responses by experienced and inexperienced investors reveal the prominent role of information. If saving the investment already in place were the main motive for experienced investors to add to the existing stake, then in the absence of information asymmetries it is hard to explain the absence of FDI to domestic firms that were in conceivably worse financial need. Suppose that a foreignowned firm established pre-crisis is in need of funds to stay in business. The foreignowned subsidiary could opt to borrow from banks at a high liquidity premium, and the possibility of additional investment from its mother company makes it more likely for it to obtain loans than domestic firms that have no such foreign investment connection. 6 The foreign-owned subsidiary may also receive FDI from its mother company. The opportunity cost of providing FDI to the foreign-owned subsidiary for the mother company is quite high however, since there are many domestic firms with capital in place willing to accept foreign direct investment. The absence of FDI to domestic firms indicates that there is a very high cost in searching and evaluating host firms.

\footnotetext{
5 Consistent with an explanation for FDI based on superior information on the part of foreign investors, Hausmann and Fernández-Arias (2001) and Albuquerque (2003) find that FDI as a fraction of capital inflows is higher in riskier countries, measured either by countries' sovereign credit ratings and other measures of country risk, and Mody et al. (2002) show with country-level data that foreign investors have information advantages in countries having low corporate governance and accounting standards.

6 The premium for liquidity measured by the Korean short-term interest rate jumped from about $13 \%$ in November 1997 to $23 \%$ in December 1997, and fell back to $12 \%$ in July 1998. But at the high premium there was evidence that liquidity was available. Borensztein and Lee (2002) with firm level data for Korea find no credit contraction in the first half of 1998. They find that total bank borrowing increased both in absolute terms and relative to other forms of finance for the average firm over the first half of 1998.
} 
Figure 1: Exchange Rate (Korean won/U.S. dollar): three-month moving average

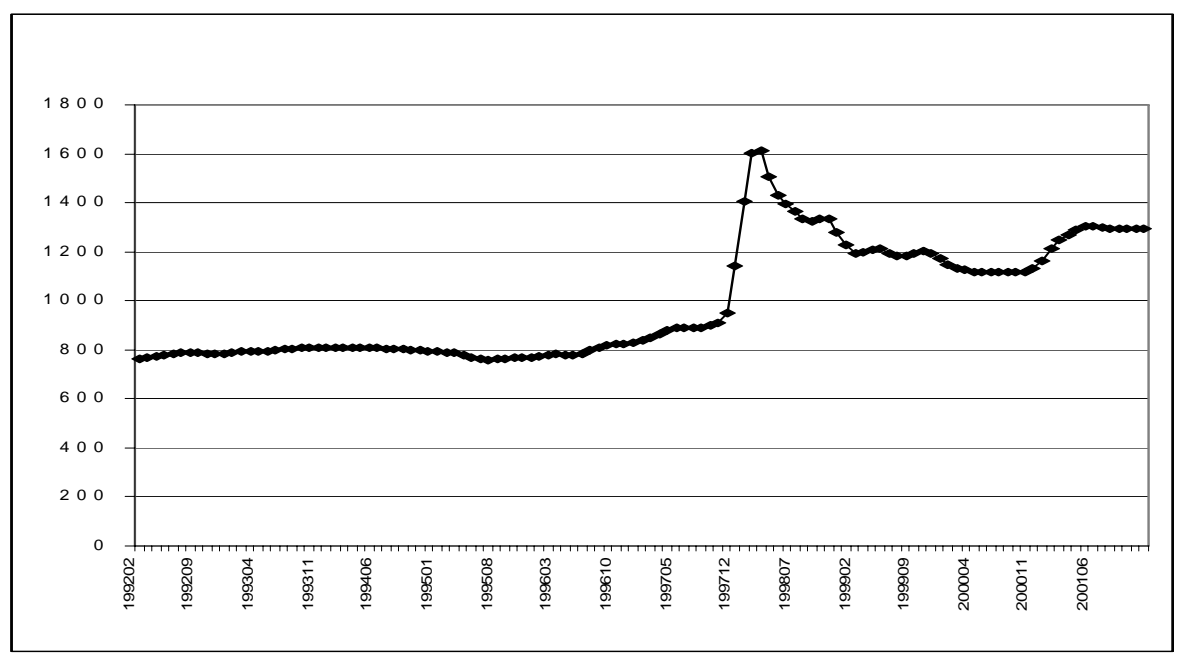

Our empirical test is based on micro-data on inward FDI to Korea before, during and after the 1997 Asian financial crisis. The behavior of the Korean won/US dollar exchange rate is extraordinary over 1997-1998 as shown in Figure 1. Before the collapse of the Korean won during the financial crisis, the currency was under a managed floating exchange rate regime where daily fluctuation of the spot rate was restricted within a band relative to the U.S. dollar. During the Asian financial crisis, the won/dollar rate jumped from 965 in October of 1997 to 1695 in December 1997 before settling down to about 1200 in the beginning of 1999. The sharp depreciation of the won made assets denominated in the Korean currency much cheaper for foreign investors from the end of 1997 through 1998, but was also a period characterized by considerable uncertainty about the data generating model.

Despite the heightened uncertainty, FDI to Korea in the twelve month period after the outbreak of crisis in November 1997 rose by $70 \%$ in U.S. dollar value over that of the preceding twelve months. A disproportionately high fraction of the FDI made immediately following the onset of the crisis (about 52\% compared to $36 \%$ before the crisis) came from foreign investors with previous experience compared to foreign investors with no previous experience in Korea. In negative-binomial regressions, the number of FDI counts from informed investors, indicated by experience of investor and large size of FDI, are much more responsive to changes in exchange rates and exchange rate uncertainty than that from less informed investors. In the binomial logit regressions, controlling directly for size of FDI and host firm affiliation, we find that FDI by investors with experience is significantly more likely when exchange rate uncertainty is high than is FDI by other investors. The results confirm that information of investors is a critical determinant of firm-level FDI response to the exchange rate during a period of heightened uncertainty.

The paper is organized as follows. Section 2 presents a model of investment under uncertainty with Bayesian learning. Section 3 describes the FDI data. Section 4 presents estimates of negative binomial and multinomial logit regression models of FDI. Section 5 concludes. 


\section{$2 \quad$ A Model of Investment under Uncertainty with Bayesian Learning}

\subsection{The Specifics of the Model}

The key difference between our model and the option value theory of investment under uncertainty lies in the investor's information structure. In the model an investor observes a signal of expected return to a project, and chooses between investing in the project in the current period and waiting to reconsider investment in the next period. The investor must deal with the objective uncertainty in the data given the model and the subjective uncertainty about the data-generating model. ${ }^{7}$ To highlight the importance of the role of investor's information, we set up a model in which all uncertainty in data (objective uncertainty) depends on the state of the macroeconomy. The macroeconomic shock generates a signal for each project. The signal comes from the same distribution but may be different ex-post for each project. The investors may respond differently to the same observed signals, due to difference in investor information. The expected return depends on the state of the economy and on an investor's assessment of the impact of the state of the economy on the return of his prospective project.

It is assumed that there are two states of the macroeconomy; state 1, a high uncertainty state or crisis state for emphasis, and state 2, a normal state. When the economy is in the high uncertainty state, the potential expected return on a project has a macroeconomic scaling factor $M_{t}=m_{1}$ that is larger than that in the normal state with $M_{t}=m_{2}\left(<m_{1}\right)$. Note that the larger potential expected return corresponds to a crisis state with low asset price. Expected return on a project is given by

$$
x_{t}=\rho M_{t}+\varepsilon_{t},
$$

where the parameter $\rho$ is unknown to the investor and $\varepsilon_{t}$ follows a normal distribution with mean zero and variance $\sigma_{t}^{2}, N\left(0, \sigma_{t}^{2}\right)$. The variance of the draw is $\sigma_{t}^{2}=\sigma_{1}^{2}$ in the high uncertainty state and is $\sigma_{t}^{2}=\sigma_{2}^{2}$ in the normal state, with $\sigma_{2}^{2}<\sigma_{1}^{2}$. The state of the economy (and the values of $M_{t}$ and $\sigma_{t}^{2}$ ) is known in each period to investors. A key assumption is that the mean expected return on the project, $\rho M_{t}$, is unknown to the investor. The transition probabilities for economy-wide uncertainty of the next period $(j)$ conditioning on the current state $(i)$ are given by $p_{i, j}$, with $\sum_{j=1}^{2} p_{i, j}=1$ for $i=1,2$.

When the economy is hit by a crisis, the potential return (indicated by $M$ ) is known to be higher, but the impact on the project is not known to the investor. A larger potential expected return corresponds to a crisis state with low asset price. It is plausible to assume that a large number of investors believed that the potential return is increased despite the atypical uncertainty. Note that the assumption of increase in potential

7 The model differs from that in McDonald and Siegel (1986), Dixit (1989), and Dixit and Pindyck (1994) in which investors know the model that generates signals. In the benchmark model of an infinite horizon continuous time framework with the return following the Brownian motion (the continuous time version of discrete time random walk) there exists an analytical solution for optimal timing of investment. 
expected return does not imply the expected return for each project is higher, due to the randomness in parameter $\rho .8$ Some projects are more affected by crisis than others. The investor learns about the implication of the state of the economy on the project under consideration as more data become available over time. The new data are combined with prior information through Bayesian learning.

The prior information on $\rho$ of the investor before observing any data is assumed to be a normal distribution $N\left(\rho_{0}, \omega_{0}^{2}\right)$. The initial prior may be different for different investors. A higher value for $\omega_{0}^{2}$ indicates a higher ex-ante uncertainty for an investor's return on his project. We argue that in the absence of empirical evidence that suggests otherwise, it is plausible to model the prior of firm-specific $\rho$ as normally distributed for an investor. The normality assumption on the prior and data makes Bayesian updating easy to model. Assuming prior takes a non-normal distribution will not qualitatively change the result of the model but will complicates the algebra.

The other source of the difference in investors' information is the number of observations drawn from the project at a given state of the economy. The period-t prior about the parameter $\rho$ (before observing the signal in the period) is denoted as function $\varphi$. The investor's knowledge (the posterior) after observing the period-t signal is denoted by $\widetilde{\varphi}$. The normality of the posterior follows from that of the model and the normality of the prior.

An investor has two possible courses of action. First, he may make the investment in the current period; second, he may wait to the next period before taking any action. Without causing confusion, we drop the subscript that represents the state of the economy. Let $\mathrm{V}(\mathrm{s}, x, \varphi)$ be the value of project when the current expected return is $x$ and the variance of $x$ is $\sigma^{2}$ in state $s$ conditioning on parameter $\rho$. The next period expected return is $x$ '.

The dynamic programming problem is characterized by the Bellman's equation:

$$
V(s, x, \varphi)=\max \left\{x, 0, E V\left(s^{\prime}, x^{\prime}, \widetilde{\varphi} \mid s, x, \varphi\right) /(1+r)\right\} .
$$

The value of waiting before discounting, $E V\left(s^{\prime}, x^{\prime}, \widetilde{\varphi} \mid s, x, \varphi\right)$, is the conditional expectation with respect to the macro state of the next period $\left(s^{\prime}\right)$, the next period's signal $\left(x^{\prime}\right)$, and the posterior $(\widetilde{\varphi})$ of parameter $\rho$, given the current macro-state $(s)$, the observed signal $(x)$, and investor's prior $(\varphi)$.

The normality of the prior of $\rho$ implies that it can be captured by the mean and variance parameters, with $\varphi$ proportional to $N\left(\bar{\rho}, \bar{\omega}^{2}\right)$. The updating of investor's knowledge (from $\varphi$ to $\widetilde{\varphi}$ ) is based on Bayes rule. Given the current macro-state s (without causing confusion we drop the subscript of the macro state here), the investor knows $M$ and $\sigma$ but does not know $\rho$. The investor also observes the signal from a host

\footnotetext{
8 The situation in which a crisis raises potential expected mean is interesting to analyze. The conclusion we obtain, that the informed investors have lower threshold of required return still holds if we assume the potential expected is not increased by crisis. During the Asian crisis the sharp depreciation of domestic currency is temporarily far beyond the long term purchasing power parity level, so that overall FDI becomes inexpensive. As we discuss below, in the wake of crisis overall FDI increased by about $70 \%$ in U.S. dollar value in Korea. Despite the press clippings during late 1997 and early 1998 to the effect that the Korean economy was entering a depression that could extend over time, some foreign investors clearly sensed economic opportunity.
} 
(or project) given in (1), $x$. Then given the prior $\varphi \propto N\left(\bar{\rho}, \bar{\omega}^{2}\right)$, the posterior follows a normal distribution:

$$
\widetilde{\varphi}\left(\rho \mid s, x, \bar{\rho}, \bar{\omega}^{2}\right) \propto \exp \left\{-\frac{(x-\rho M)^{2}}{2 \sigma^{2}}\right\} \exp \left\{-\frac{(\rho-\bar{\rho})^{2}}{2 \bar{\omega}^{2}}\right\} \propto N\left(\bar{\rho}^{\prime}, \bar{\omega}^{\prime 2}\right) .
$$

Here the variance of the posterior is weighted average of the prior variance and the scaled macro uncertainty:

$$
\bar{\omega}^{\prime 2}=\left(\bar{\omega}^{-2}+M^{2} \sigma^{-2}\right)^{-1} .
$$

The mean of posterior is a weighted average of the prior mean and the observed data:

$$
\bar{\rho}^{\prime}=\left(\bar{\omega}^{\prime}\right)^{2}\left(\bar{\rho} \bar{\omega}^{-2}+x M \sigma^{-2}\right) .
$$

For completeness, we provide the details on Bayesian updating that lead to posterior of (3) and (4). Suppose under macro-state $j$, the investor observes n periods of signals from a host (or project) given in (1), $X=x_{1}, \ldots x_{n}$. Then given the initial prior $N\left(\rho_{0}, \omega_{0}^{2}\right)$ the posterior of $\rho_{j}$ is

$$
\pi\left(\rho_{j} \mid x_{1}, . ., x_{n}, \rho_{0}, \omega_{0}\right) \propto \exp \left\{-\sum_{t=1}^{n} \frac{\left(x_{t}-\rho_{j} M_{j}\right)^{2}}{2 \sigma_{j}^{2}}\right\} \exp \left\{-\frac{\left(\rho_{j}-\rho_{0}\right)^{2}}{2 \omega_{0}^{2}}\right\} \propto N\left(\bar{\rho}_{j}, \bar{\omega}^{2}\right),
$$

here the variance of the posterior $\bar{\omega}^{2}=\frac{1}{p^{2}}$. The precision of the posterior $p^{2}=\frac{1}{\omega_{0}^{2}}+\sum_{t=1}^{n} \frac{M_{j}^{2}}{\sigma_{t}^{2}}$. The mean of posterior $\bar{\rho}=\bar{\omega}^{2} \tau$, where $\tau=\frac{\rho_{0}}{\omega_{0}^{2}}+\sum_{t=1}^{n} \frac{x_{t} M_{j}}{\sigma_{t}^{2}}$. The update of the posterior after observing $x^{\prime}=x_{n+1}$ and $\sigma^{\prime}=\sigma_{n+1}$ is $\left(\bar{\omega}^{\prime}\right)^{2}=\frac{1}{\left(p^{\prime}\right)^{2}}$, where the posterior variance is $\left(p^{\prime}\right)^{2}=\frac{1}{\omega_{0}^{2}}+\sum_{t=1}^{n+1} \frac{M_{j}^{2}}{\sigma_{t}^{2}}=p^{2}+\frac{M_{j}^{2}}{\left(\sigma^{\prime}\right)^{2}}$, this gives rise to (3). The posterior mean is given by $\bar{\rho}^{\prime}=\left(\bar{\omega}^{\prime}\right)^{2}\left(\frac{\rho_{0}}{\omega_{0}^{2}}+\sum_{t=1}^{n+1} \frac{x_{t} M_{j}}{\sigma_{t}^{2}}\right)=\left(\bar{\omega}^{\prime}\right)^{2} \tau^{\prime}$, and $\tau^{\prime}=\frac{\rho_{0}}{\omega_{0}^{2}}+\sum_{t=1}^{n+1} \frac{x_{t} M_{j}}{\sigma_{t}^{2}}=\tau+\frac{x^{\prime} M_{j}}{\left(\sigma^{\prime}\right)^{2}}=\frac{\bar{\rho}}{\bar{\omega}^{2}}+\frac{x^{\prime} M_{j}}{\left(\sigma^{\prime}\right)^{2}}$, hence (4) is obtained.

The Bayesian updating implies a shrinking posterior variance $\left(\bar{\omega}^{\prime}<\bar{\omega}\right)$, i.e., as the investor observes more data, his uncertainty about the parameter $\rho$ is reduced. There is a reduction in posterior mean if the observation is lower than the prior mean $\left(\bar{\rho}^{\prime}<\bar{\rho}\right.$ if $\left.x<\bar{\rho} M\right)$.

With Bayesian updating, the Bellman equation (2) can be rewritten as

$$
\begin{aligned}
& V\left(s_{i}, x, \bar{\rho}, \bar{\omega}^{2}\right)=\max \left\{x, 0, E V\left(s^{\prime}, x^{\prime}, \bar{\rho}^{\prime}, \bar{\omega}^{2 \prime} \mid s_{i}, x, \bar{\rho}, \bar{\omega}^{2}\right) /(1+r)\right\} \\
& =\max \left\{x, 0, \sum_{j=1}^{2} p_{i, j} \iint V\left(s_{j}, x_{j}^{\prime}, \bar{\rho}^{\prime}, \bar{\omega}^{2 \prime}\right) l\left(x_{j}{ }^{\prime} \mid \rho, s_{j}\right) \widetilde{\varphi}\left(\rho \mid \bar{\rho}^{\prime}, \bar{\omega}^{2 \prime}\right) d \rho d x_{j}{ }^{\prime} /(1+r)\right\},
\end{aligned}
$$


where $\bar{\rho}^{\prime}, \bar{\omega}^{21}$ are given by (3) and (4),

$$
\begin{aligned}
l\left(x_{j}{ }^{\prime} \mid \rho, s_{j}\right) & =\left(\sqrt{2 \pi} \sigma_{j}\right)^{-1} \exp \left\{-\left(x^{\prime}-\rho M_{j}\right)^{2} /\left(2 \sigma_{j}{ }^{2}\right)\right\}, \text { and } \\
\widetilde{\varphi}\left(\rho \mid \bar{\rho}^{\prime}, \bar{\omega}^{\prime 2}\right) & =\left(\sqrt{2 \pi} \bar{\omega}^{\prime}\right)^{-1} \exp \left\{-\left(\rho-\bar{\rho}^{\prime}\right)^{2} /\left(2 \bar{\omega}^{\prime 2}\right)\right\} .
\end{aligned}
$$

The model in (2) extends the notion of uncertainty in the standard option value of investing in two ways. First, as noted earlier, the measure of uncertainty depends on the investor's information and is updated over time. Second, both the posterior mean and variance of the future signal $x$ ' are subject to the influence of the prior. Hence in a crisis state the uncertainty in the mean as well as variance are amplified. This means that the investor's information plays a more important role during crisis.

\subsection{The Threshold for Investing}

The solution of the optimal investment problem (2) can be also characterized by a threshold $x^{*}$ at which the investor is indifferent between making investment and waiting (assuming the value of option is greater than zero), $x^{*}=E V\left(s^{\prime}, x^{\prime}, \widetilde{\varphi} \mid s, x^{*}, \varphi\right) /(1+r)$. The optimal threshold depends on the investor's assessment of parameter uncertainty and the state of the economy. The overall uncertainty of the investor about $x$ ' of the next period is given by the predictive density of $x$, defined as $f\left(x^{\prime} \mid s_{i}, x, \varphi\right)=\sum_{j=1}^{2} p_{i, j} \int l\left(x^{\prime} \mid \rho, s_{j}\right) \widetilde{\varphi}\left(\rho \mid \bar{\rho}^{\prime}, \bar{\omega}^{2 \prime}\right) d \rho$, obtained through weighing the normal likelihood of $x$, for each value of parameter $\rho$ by the posterior of $\rho$ after current period observation of $x$ at state $s_{i}$. The result is a mixture of normal distributions:

$$
f\left(x^{\prime} \mid s_{i}, x, \varphi\right)=\sum_{j=1}^{2} p_{i, j} N\left(\bar{\rho}^{\prime} M_{j}, \sigma_{j}^{2}+M_{j}^{2} \bar{\omega}^{\prime 2}\right) .
$$

The result (5) follows by integrating out parameter $\rho$ in macro state $\mathrm{j}$ and completing terms for $x^{\prime}$. For completeness the derivation is provided here (with the proportional constants omitted in the density function):

$$
\begin{aligned}
& f\left(x^{\prime} \mid s_{i}, x, \varphi\right)=\sum_{j=1}^{2} p_{i, j} \int l\left(x^{\prime} \mid \rho_{j}, s_{j}\right) \widetilde{\varphi}\left(\rho_{j} \mid \bar{\rho}^{\prime}, \bar{\omega}^{2 \prime}\right) d \rho_{j} \\
& \propto \sum_{j=1}^{2} p_{i, j} \int \exp \left\{-\frac{\left(x^{\prime}-\rho_{j} M_{j}\right)^{2}}{2 \sigma_{j}^{2}}\right\} \exp \left\{-\frac{\left(\rho_{j}-\bar{\rho}^{\prime}\right)^{2}}{2 \bar{\omega}^{\prime 2}}\right\} d \rho_{j} \\
& \propto \sum_{j=1}^{2} p_{i, j} \int \exp \left\{-\frac{1}{2}\left[\frac{x^{\prime 2}}{\sigma_{j}^{2}}+\left(\frac{M_{j}^{2}}{\sigma_{j}^{2}}+\frac{1}{\bar{\omega}_{j}^{\prime 2}}\right)\left(\rho_{j} x_{j}^{\prime}-\frac{\bar{\sigma}_{j}^{\prime}}{\left.\frac{M_{j}^{2}}{\bar{\omega}_{j}^{\prime 2}}+\frac{1}{\bar{\omega}_{j}^{\prime 2}}\right)^{2}}-\frac{\left(\frac{M_{j} x^{\prime}}{\sigma_{j}^{2}}+\frac{\bar{\rho}^{\prime}}{\bar{\omega}_{j}^{\prime 2}}\right)^{2}}{\frac{M_{j}^{2}}{\sigma_{j}^{2}}+\frac{1}{\bar{\omega}_{j}^{\prime 2}}}\right]\right\} d \rho_{j}\right.
\end{aligned}
$$




$$
\begin{aligned}
& \propto \sum_{j=1}^{2} p_{i, j} \exp \left\{-\frac{1}{2}\left[\frac{x^{\prime 2}}{\sigma_{j}^{2}}-\frac{\left(\frac{M_{j} x^{\prime}}{\sigma_{j}^{2}}+\frac{\bar{\rho}^{\prime}}{\bar{\omega}_{j}^{\prime 2}}\right)^{2}}{\frac{M_{j}^{2}}{\sigma_{j}^{2}}+\frac{1}{\bar{\omega}_{j}^{\prime 2}}}\right]\right\} \\
& \propto \sum_{j=1}^{2} p_{i, j} \exp \left\{-\frac{1}{2}\left[\frac{\left(x^{\prime}-\bar{\rho}^{\prime} M_{j}\right)^{2}}{\bar{\omega}^{\prime 2} M_{j}^{2}+\sigma_{j}^{2}}\right]\right\} \\
& \sim \sum_{j=1}^{2} p_{i, j} N\left(\bar{\rho}^{\prime} M_{j}, \bar{\omega}^{\prime 2} M_{j}^{2}+\sigma_{j}^{2}\right) .
\end{aligned}
$$

Equation (5) shows that for each given state of economy, the uncertainty in the investor's predicted draw of signal of the next period is the sum of the uncertainty in data, $\sigma^{2}$, and the uncertainty of investor's assessment in the mean of the expected return, $M^{2} \bar{\omega}^{\prime 2}$. With smaller posterior variance, $\bar{\omega}^{\prime 2}$, the variance of predicted $x^{\prime}$ is smaller, and the value of option for waiting is lower. Thus, for the same level of objective uncertainty, a better informed investor has a lower threshold for current investment than a less informed investor. Investor knowledge makes a particularly large difference when the economy is in the high uncertainty state because the posterior variance $\bar{\omega}^{\prime 2}$ is amplified by the higher macroeconomic scaling factor $M_{j}$. In the absence of subjective uncertainty about parameter $\rho, \bar{\omega}^{\prime}$ is zero, and the problem becomes one of standard value of option for investment, in which increases in uncertainty $\sigma$ raise the threshold of required returns.

Subjective uncertainty also affects the value of waiting in a more subtle way. High values of the current-period signal $x$ result in substantial increase in the posterior mean $\bar{\rho}^{\prime}$ for uninformed investors (characterized by a large parameter $\omega$ ), compelling a wait for a better draw in the future. An informed investor (with the same prior mean as the uninformed investor) on the other hand, who's posterior on parameter $\rho$ is less influenced by the current data, is more likely to act on the current high draw. The uninformed investor also revises his posterior more than an informed investor after observing a low value of the current-period signal $x$, but the subjective uncertainty makes no difference in this case because neither investor invests at the low draw. Hence the net effect of larger subjective uncertainty is slower delivery of investment, particularly by the less informed.

The substance of this and the previous section is summarized in the following remarks. In the present model the option value of waiting depends on the investor's uncertainty on the prospect of the project, and the uncertainty diminishes as the investor observes more signals of the project (as the updating formula (3) implies). For an informed investor, the uncertainty $\bar{\omega}$ is small and the threshold of $x$ that triggers investment is lower than that of an uninformed investor. This means that for the same macroeconomic uncertainty, the informed investors are more likely to commit funds than uninformed investors.

In the model larger macro-uncertainty raises the option value of waiting by making the option more valuable given investor's knowledge about the prospect of the project. 
In addition, as the updating formula (3) makes clear, if crisis amplifies project uncertainty $\sigma$ more than it does potential return through the scaling factor $M$, then the signal $x$ becomes noisier in the crisis period, and the precision of the posterior is improved more slowly, which also makes waiting more desirable. If on the other hand, crisis increases potential return through the scaling factor $M$ by more than it does uncertainty, precision of the posterior is improved more rapidly, which makes waiting less desirable.

\subsection{A Numerical Example}

The optimal investment decision is affected by the mean as well as the variance of expected return perceived by the investor, both of which are amplified during a crisis state, the net of the offsetting effects may make the invest more or less likely, depends on the parameters in the data generating model as well as the investor's prior information. To examine the properties of the theoretical model intuitively, we will now present some numerical results on the optimal policy. We draw the expected return $x$ using model (1). We then simulate the distribution of the threshold of the experienced investor, $x^{*}$, and calculate the number of cases that have the threshold $x^{*}$ above the simulated data $x$.

We assume for state 1 , or crisis state, $m_{1}=1.0$ and $\sigma_{1}=0.2$ and for state 2 , or normal state, $m_{2}=0.5$ and $\sigma_{2}=0.05$. If the economy is at the crisis state, the probability of staying in such state is 0.8 ; and if the economy is at a normal state, the probability of staying in such state is 0.999 . We let the discount rate $r=0.01$. Simulations show that higher discount rates produce qualitatively the same result. We consider the case that there are 4 types of investor firms, each numbers 10,000 in period $t=1$. The four types of firm observe draws from the same distribution of expected returns governed by (1), with the parameter $\rho=0.2$ and face the same macro state. A type $i$ investor firm $(i=1, . .4)$ is characterized by an ex-ante identical initial prior parameter $\rho$ centered at 0.2 but with a standard deviation ranging from 0.1 for type 1 to 0.7 for type 4 . By design, the only difference across potential projects ex-ante is the investor's uncertainty concerning the prospect of the project, and simulation results are not driven by informed investors having higher ex ante returns on projects.

For each potential project, we simulate 5 periods of expected returns from model (1) and update the investor's posterior for the parameter $\rho$. The realized states are: crisis for $\mathrm{t}=1$, and normal states for $\mathrm{t}=2,3,4,5$. We start the simulation at the crisis state so that the numbers of investors with given information sets at the time of crisis can be perfectly controlled. Therefore ex-post difference in investment decisions across different types of investor firms is solely due to the initial information sets of investors. A more realistic model assumption is that for each firm the initial prior for parameter $\rho$ is dependent on the state of the macroeconomy, hence only observing signals from a project during normal state of the economy does not help in reducing the investor' uncertainty about the project when the economy switches to a crisis state. By starting at a crisis state, we can avoid the complicating assumption of state-dependent initial priors and still produce simulation results that are approximately consistent with such a model. In the simulation, if the expected return drawn is above the threshold level given the current posterior of investor uncertainty and macro state, then the project is funded and 
taken out of the pool of 10,000 potential projects. To evaluate the conditional expectation in (2), we use 10 point Gauss-Hermit quadrature to proxy distribution of continuous random variable, which is appropriate for normally distributed errors. We found through experiments that the approximation is highly accurate and much faster than grid search method.

Note that the analysis of the theoretical model indicates that investor's uncertainty about parameter $\rho$ is reduced over time as more data are observed, and the threshold of the expected return is lower when the investor's uncertainty is lower. Investors' initial priors reflect a high degree of uncertainty and it takes more observations to reduce the posterior variance of $\rho$ to a given level. It follows that these investors tend to take longer to decide to invest for a given set of observed data. When a financial crisis hits the economy, the mean and the variance of expected return are both high. As equation (5) shows, the uncertainty for the signal of next period is given by the sum of (objective) macro uncertainty $\sigma^{2}$ and (subjective) investor's project-specific uncertainty $\bar{\omega}^{2} M^{2}$. For an investor with a high subjective uncertainty $\left(\bar{\omega}^{2}\right)$, the higher potential return $M$ amplifies the overall uncertainty. For an investor with a small $\bar{\omega}^{2}$, the larger potential return mainly represents a profitable opportunity. It is more likely that the informed investor will take advantage of the higher potential return.

Table 1. Simulation Results of Investment with Uncertainty about Model Parameters (10,000 potential projects for each investor type)

\begin{tabular}{|c|c|c|c|}
\hline $\begin{array}{c}\text { Standard deviation of } \\
\text { initial prior }\end{array}$ & \multicolumn{3}{|c|}{ Simulated count of invested projects in 5 periods } \\
\cline { 2 - 4 } $\begin{array}{c}\text { Lower } \bar{\omega}_{0}^{2} \text { indicates less } \\
\text { uncertainty about } \\
\text { parameters) }\end{array}$ & $\begin{array}{c}\text { During crisis } \\
\text { period } \\
\text { (State 1) }\end{array}$ & $\begin{array}{c}\text { During 4 periods } \\
\text { after the crisis (State } \\
\text { 2) }\end{array}$ & Total over time \\
\hline Type 1: $\bar{\omega}_{0}^{2}=0.1$ & 3198 & 3675 & 6873 \\
\hline Type $2: \bar{\omega}_{0}^{2}=0.3$ & 2358 & 3490 & 5848 \\
\hline Type 3: $\bar{\omega}_{0}^{2}=0.5$ & 1540 & 3731 & 5271 \\
\hline Type 4: $\bar{\omega}_{0}^{2}=0.7$ & 1030 & 3886 & 4916 \\
\hline Total count of \\
Investment
\end{tabular}

Notes: Macro scaling factor $m_{1}=1.0$ and $m_{2}=0.5$, macro-uncertainty $\sigma_{1}=0.2, \sigma_{2}=0.05$, the investor's prior distribution prior on $\rho$ is $N\left(\rho_{0}, \bar{\omega}_{0}^{2}\right)$, initial $\rho_{0}=0.2$ for all investor types.

The simulation results confirm the above intuition. Note that the data for all investors are generated from the same distribution. But the most informed investors (with smallest standard deviation of 0.1 in the initial prior) made more investment (close to $32 \%$ of them did so) in the crisis period than the least informed investors with the largest standard deviation of 0.7 in the initial prior (only about $10 \%$ of them did so). If the first group is labeled as informed (or experienced) investors, and the rest as less experienced investors, then during the crisis period investment from the experienced investors account for $39 \%$ (3198 out of 8126 ) of the total cases, and after the crisis only $25 \%$ (3675 out of 14782$)$. 


\subsection{Empirical Implications}

The model predicts that informed investors respond more quickly to situations in which macroeconomic uncertainty is increased. Note that for the sake of simplicity, the theoretical model ignores many important factors in investment decisions, and should be viewed as illustrative instead of empirical. We will not try to strictly match the numerical simulation with the Korean data for that reason. The change in macro uncertainty and the mean of expected return affect the investors' decision. The regression results reported later in the paper give marginal effect of the shifts in macro uncertainty (in exchange rate) and shifts in the mean of expected return, controlling other factors.

One factor omitted from the theoretical model is the cost of information acquisition. We assume that in every period there is one signal observed without cost. In reality, assessment on investment projects typically involves substantial costs that may prevent many investors from obtaining new information on a regular basis. If the cost of information acquisition per dollar of investment is negatively correlated with the size of the investment, then one should expect large FDI to occur relatively more frequently around the time of crisis. This implication of the model will be examined in subsequent sections. 9

\section{The Korean FDI Data}

Monthly data on firm level inward FDI to Korea is from Invest Korea, Korea Trade and Investment Promotion Agency in the Ministry of Commerce, Industry \& Energy. Between January 1996 and December 2001, there are 10,405 observations on FDI. Data are available on FDI for several earlier years, but this data set is used to identify FDI events in the period starting in January 1996 as being first-time or repeat FDI by investors. ${ }^{10}$ A substantial cost in making FDI is the intangible cost in collecting information on potential projects which we believe is influenced by the experience of the foreign investor. ${ }^{11}$ The specific affiliation characteristics of a foreign investor firm is its experience in making FDI in Korea, including repeated FDI experience with a specific host firm, and whether or not it has managerial control over the host firm.

Table 2 reports the size distribution of FDI events over 1994:11-2001:10, with data reported annually starting in November so as to capture behavior over the financial

9 In trade theory, Rauch and Trindade (2003) show that improved information makes trade more responsive to international price differentials. Our argument on the exchange rate and FDI is analogous to their argument.

10 We start count investor experience from year 1992 (so the investor's information is likely relevant for the sample period considered). Some foreign investors have started investing in Korea prior to January 1996 (but after 1992), in which case their FDI activity during the sample will be correctly identified as experienced rather than as first-time.

11 These costs include the foreign investor being required to file notification to the Korea Investment Service Center (KISC) or to domestic and overseas trade centers of KOTRA (Invest Korea, Korea Trade and Investment Promotion Agency). The notification within the scope of industries permitted for foreign investment appears to be a formality. At the time of notification, tangible costs of incorporation expenses are on average $3 \%$ in metropolitan areas and about $2 \%$ outside metropolitan areas (Invest Korea). 
crisis reflected in accelerated deterioration in the value for the Korean won starting in November of 1997. A striking feature of the data in Table 2 is that the dollar value of FDI from November, 1997 to October, 1998 was 69\% higher than FDI in the immediately preceding twelve months. The size distribution exhibits an interesting time-varying pattern in that the average size of FDI is larger in the post-crisis period starting in November 1997 than in the 12-month period immediately before the financial crisis.

A major event occurred at the end of 1998 with relaxation of capital control by the Korean Government in November 1998. Since the 1980s, the Korean government has adopted a series of measures of capital liberalization. On regulations concerning FDI, a

Table 2. Size Distribution of FDI in Korea over 1994:11-2001:10

\begin{tabular}{|c|c|c|c|c|c|c|c|}
\hline \multirow{2}{*}{$\begin{array}{c}\text { Size of FDI } \\
\text { (millions US } \\
\text { dollars) }\end{array}$} & \multicolumn{7}{|c|}{ Number of FDI } \\
\hline & $\begin{array}{l}\text { 1994:11- } \\
1995: 10\end{array}$ & $\begin{array}{c}1995: 11- \\
1996: 10\end{array}$ & $\begin{array}{c}1996: 11- \\
1997: 10 \\
\end{array}$ & $\begin{array}{c}\text { 1997:11- } \\
\text { 1998:10 }\end{array}$ & $\begin{array}{c}\text { 1998:11- } \\
\text { 1999:10 }\end{array}$ & $\begin{array}{l}\text { 1999:11- } \\
\text { 2000:10 }\end{array}$ & $\begin{array}{l}2000: 11- \\
2001: 10 \\
\end{array}$ \\
\hline$F D I \geq 1000$ & 0 & 0 & 0 & 0 & 1 & 1 & 0 \\
\hline $\begin{array}{c}1000>F D I \geq \\
200\end{array}$ & 0 & 0 & 2 & 3 & 6 & 9 & 6 \\
\hline $\begin{array}{c}200>F D I \geq \\
100\end{array}$ & 0 & 2 & 2 & 8 & 9 & 13 & 6 \\
\hline $\begin{array}{c}100>F D I \geq \\
10\end{array}$ & 26 & 40 & 57 & 86 & 102 & 113 & 101 \\
\hline $10>F D I \geq 1$ & 152 & 182 & 222 & 237 & 235 & 334 & 311 \\
\hline $1>$ FDI & 533 & 709 & 685 & 823 & 1045 & 3539 & 2309 \\
\hline Total & 711 & 933 & 968 & 1157 & 1398 & 4009 & 2733 \\
\hline Size of FDI & \multicolumn{7}{|c|}{ Amount of FDI-millions US dollars } \\
\hline $\begin{array}{c}\text { (millions US } \\
\text { dollars) }\end{array}$ & $\begin{array}{l}1994: 11- \\
1995: 10\end{array}$ & $\begin{array}{c}1995: 11- \\
1996: 10 \\
\end{array}$ & $\begin{array}{c}1996: 11- \\
1997: 10 \\
\end{array}$ & $\begin{array}{c}\text { 1997:11- } \\
\text { 1998:10 }\end{array}$ & $\begin{array}{c}\text { 1998:11- } \\
\text { 1999:10 }\end{array}$ & $\begin{array}{l}\text { 1999:11- } \\
\text { 2000:10 }\end{array}$ & $\begin{array}{l}2000: 11- \\
2001: 10\end{array}$ \\
\hline$F D I \geq 1000$ & 0 & 0 & 0 & 0 & 1,612 & 1,342 & 0 \\
\hline $\begin{array}{c}1000>F D I \geq \\
200\end{array}$ & 0 & 0 & 502 & 941 & 1,519 & 3,122 & 2,196 \\
\hline $\begin{array}{c}200>F D I \geq \\
100\end{array}$ & 0 & 309 & 300 & 1,223 & 1,106 & 1,726 & 777 \\
\hline $\begin{array}{c}100>F D I \geq \\
10\end{array}$ & 600 & 915 & 1,485 & 2,179 & 3,011 & 3,473 & 2,664 \\
\hline $10>F D I \geq 1$ & 424 & 534 & 653 & 723 & 840 & 1,095 & 979 \\
\hline $1>\mathrm{FDI}$ & 128 & 173 & 158 & 165 & 155 & 316 & 277 \\
\hline Total & 1152 & 1,930 & 3,099 & 5,231 & 8,244 & 11,075 & 6,894 \\
\hline
\end{tabular}

Source of data: Invest Korea, Korea Trade and Investment Promotion Agency, Ministry of Commerce, Industry \& Energy, Seoul, Korea. 
new FDI regime passed by National Assembly on September $2^{\text {nd }}, 1998$, and effective November $17^{\text {th }}, 1998$ was a landmark event. This legislation instituted policies designed to expedite and encourage FDI through tax advantages, reduction in restrictions and red tape, and opening of previously restricted sectors. These changes reduce the cost of FDI in Korea. ${ }^{12}$ The relaxation of capital control resulted in a further surge in FDI into Korea as the information in Table 2 indicates.

Table 3 shows the counts and amounts of FDI made over 1996:1-2001:12 grouped by host firm type and by investor experience profile. From the Table 3 it is seen that the story of FDI in Korea over 1996:1-2001:12 is overwhelmingly about foreign investors making investment in unlisted host firms (that are not publicly traded) rather than in listed firms on KSE and KOSDAQ. A firm is taken as foreign-owned if it bears the same name as the foreign investor. Of 4099 FDI received by foreign-owned firms, only 30 FDI were received by foreign-owned firms listed in Korea. Unlisted (majority owned) domestic firms received 6068 FDI and listed firms received 268 FDI (including the 30 FDI to foreign-owned listed firms).

Of all 10,405 FDI events over 1996:1-2001:12, 3119 events were by investors as second or subsequent experiences of FDI in Korea. Cases with FDI made by an investor with experience are $30.0 \%$ of the number of cases and $50.7 \%$ of the amount of FDI. Furthermore, Table 3 shows that the count of FDI involving the same investor/host firm pair (at their second and subsequent interactions since 1992) is 2418. It is striking that during the short period following outbreak of the Asian Financial crisis in Korea during which the won is at its lowest value, 1997:11-1998:7, the share of total FDI in value by investors with paired experience is $52.4 \%$, higher than the $35.9 \%$ share for the pre-crisis period 1996:1-1997:10 and the 40.1\% share for the post-crisis period 1998:8-2001:12. Further, the counts of FDI larger than one million dollars made by experienced investors constitute $15.4 \%$ of total FDI counts for the sample period 1996:1-1998:10 and 10\% of total counts for the whole sample 1996:1-2001:12.

The cross time and cross sectional dimensions of the FDI incidence motivates the regression analyses of the present study. The negative binomial regression captures the variation of counts of FDI by one type of investor with macroeconomic variables, and the binomial logit regression captures the variation of monthly composition of FDI cases while controlling for microeconomic characteristics of firms and FDI. The regressions are based on the whole sample period 1996:1-2001:12 as well as the shorter period 1996:1-1998:10, before the relaxation of capital controls. Note that the estimates for the shorter period reflect the variations of FDI counts or share of FDI from experienced investors to macroeconomic uncertainty within that period, so we learn more about the marginal effect of the macroeconomic uncertainty beyond that reflected by the summary statistics across different sample periods.

The role played by experienced foreign investors during the crisis is illustrated in Figure 2 with a plot of the 3-month moving average of the percentage of the count of FDI by foreign investors with paired experience in total count of FDI over the period

\footnotetext{
12 The tax and other incentives are targeted for larger FDI projects and for projects in certain sectors such as the high technology industries. Foreign investors benefit from exemption on rent and fees, as well as support for residential facilities such as medical, education and housing support. In designated Foreign Investment Zones foreign investors also benefit from outstanding infrastructure such as roads, railways, airports, seaports, utilities, and telecommunication facilities.
} 
Table 3. The Role of Experience in FDI Cases: 1996:1-2001:12

(average size in parentheses)

\begin{tabular}{|c|c|c|c|c|c|}
\hline \multirow{2}{*}{$\begin{array}{c}\text { Host firm type: } \\
\text { \#FDI }\end{array}$} & \multicolumn{5}{|c|}{ Number of cases of Experience } \\
\hline & Host firm & Investor & $\begin{array}{c}\text { Investor \& } \\
\text { Host firm }\end{array}$ & Paired & None \\
\hline $\begin{array}{l}\text { All firms: } \\
10405(3.52)\end{array}$ & $3180(6.09)$ & $3119(5.95)$ & $2496(6.11)$ & $2418(6.17)$ & $6137(2.29)$ \\
\hline $\begin{array}{l}\text { Foreign-owned firms: } \\
\qquad 4099(4.45)\end{array}$ & $1802(6.53)$ & $1803(7.49)$ & $1595(6.03)$ & $1574(6.03)$ & $2020(2.95)$ \\
\hline $\begin{array}{c}\text { Unlisted } \\
\text { Domestic firms: } \\
6068(2.41)\end{array}$ & $1240(4.74)$ & $1164(2.65)$ & $795(5.26)$ & $746(5.43)$ & $4025(1.62)$ \\
\hline $\begin{array}{c}\text { Listed firms } \\
\text { (Public firms): } \\
\text { 268(14.76) }\end{array}$ & $138(12.46)$ & $152(13.00)$ & $106(13.68)$ & $98(13.95)$ & $92(16.90)$ \\
\hline
\end{tabular}

Note: Investor experience - the investor has at least one prior FDI before the one counted (the host firm may or may not have FDI experience). Host firm experience - the host firm has at least one prior FDI before the one counted (the investor may or may not have FDI experience). Investor and host firm experience - both firms have had at least one prior FDI before the one counted (it may or may not have been with each other). Paired experience - the same host/investor pair had at least one prior FDI with one another before the one counted. None - first-time FDI by agents that become an experienced pair and by agents that never have a repeat FDI experience (this is slightly smaller than the number of first time FDI for both investor and host firm). The large average size of FDI to listed firms with no experience is due to two large FDI of $\$ 321$ million and $\$ 119$ million. The number of FDI by host firm's sub-categories exceeds the total number of FDI by 30, since 30 FDI went to listed foreign owned firms. An unlisted firm is taken as foreign-owned if it bears the same name as the foreign investor.

Source of data: Invest Korea, Korea Trade and Investment Promotion Agency, Ministry of Commerce, Industry \& Energy, Seoul, Korea.

1996- 2001. During the crisis period (November 1997 to July 1998), the share of counts of investors with paired experience in total counts of FDI shows an increase compared to the pre-crisis period. As the economy stabilized, FDI cases from inexperienced investors dominated with the relaxation of capital controls, until the end of the sample period when exchange rate volatility rose again.

\section{$4 \quad$ Regression Analysis}

In this paper we use two types of regression models to explore different dimensions of the data on the link between the exchange rate and inward FDI to Korea over 1996:11998:10 and 1996:1-2001:12. We estimate macro and firm-specific effects on the FDI case-counts to different categories in a negative-binomial regression and the probability 
that a given FDI incidence belongs to a particular category in a binomial logit regression.

Figure 2: Fraction of FDI count by experienced foreign investors 1996:01-2001:12

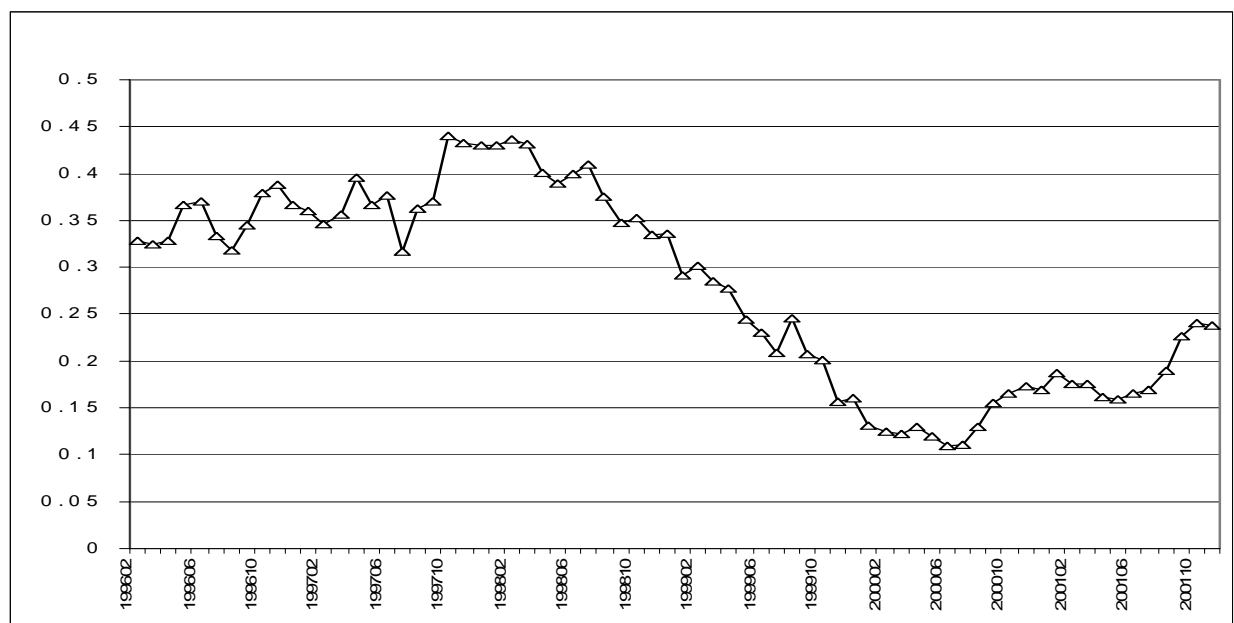

\subsection{Modeling the Monthly FDI Counts: The Negative Binomial Model}

We are interested in exploring how FDI counts by investors with different information respond to changes in macro uncertainty observable by all investors such as change in the level and volatility of exchange rates. The count data are often modeled by Poisson process. Preliminary examination of Poisson models shows substantial overdispersion. ${ }^{13}$ As a result, we consider the negative binomial model for each type of investor. The negative binomial model has a number of economic applications, e.g., see Hausman et al. (1984) and Blonigen (1997). Suppose the FDI cases of a given type $\mathrm{j}$ in period $\mathrm{t}$ is $n_{j t}$. The negative binomial model is given by $\operatorname{NB}\left(\gamma_{j t}, \delta_{j}\right)$, where $\gamma_{j t}=\exp \left(X_{t} \beta_{j}\right)$ is the mean, and $\delta$ measures over-dispersion. When the dispersion parameter approaches zero, the negative binomial model becomes Poisson.

\subsubsection{Macroeconomic Variables}

Macroeconomic variables, $X_{t}$, that will be taken to influence FDI include the exchange rate, volatility of the exchange rate, and a measure of capital control. The volatility of the exchange is meant to be a proxy variable for macro uncertainty. The 3-month moving average of the Korean won/U.S. dollar exchange rate, ex, will be used to indicate expected exchange rate. ${ }^{14}$ The logarithm of a 3-month moving average of the

13 The values of Pearson Chi-sq and deviance divided by the degrees of freedom are significantly larger than 1 in all cases.

${ }^{14}$ Cushman (1985), Froot and Stein (1991), Klein and Rosengren (1994), and Blonigen (1997) investigate the effect on FDI of the current (real value) of the exchange rate. Campa (1993) measures expected exchange rate by either (perfect foresight) of exchange rate over next 2 years or static expectation based on past two years. 
standard deviation of the daily change in the won/dollar exchange rate each month, $L(s d e x)$, will serve as a proxy for uncertainty about the exchange rate. The realized day-to-day volatility of the exchange rate is a reasonable way of capturing uncertainty about future values of the exchange rate. As a robustness check we will also use a 3-month moving average of exchange rate volatility estimated by GARCH, $L($ garch $)$, as an alternative measure of exchange rate volatility. ${ }^{15}$ Figure 3 indicates that both $L(s d e x)$ and $L$ (garch) peak during the early stages of financial crisis (with $L($ sdex)) peaking somewhat before $L($ garch $)$ ), exhibit considerable volatility throughout the 1996:1-2001:12 period, and move in line the exchange rate in Figure 2.

Figure 3: Exchange rate volatility measures: 1996:1-2001:12

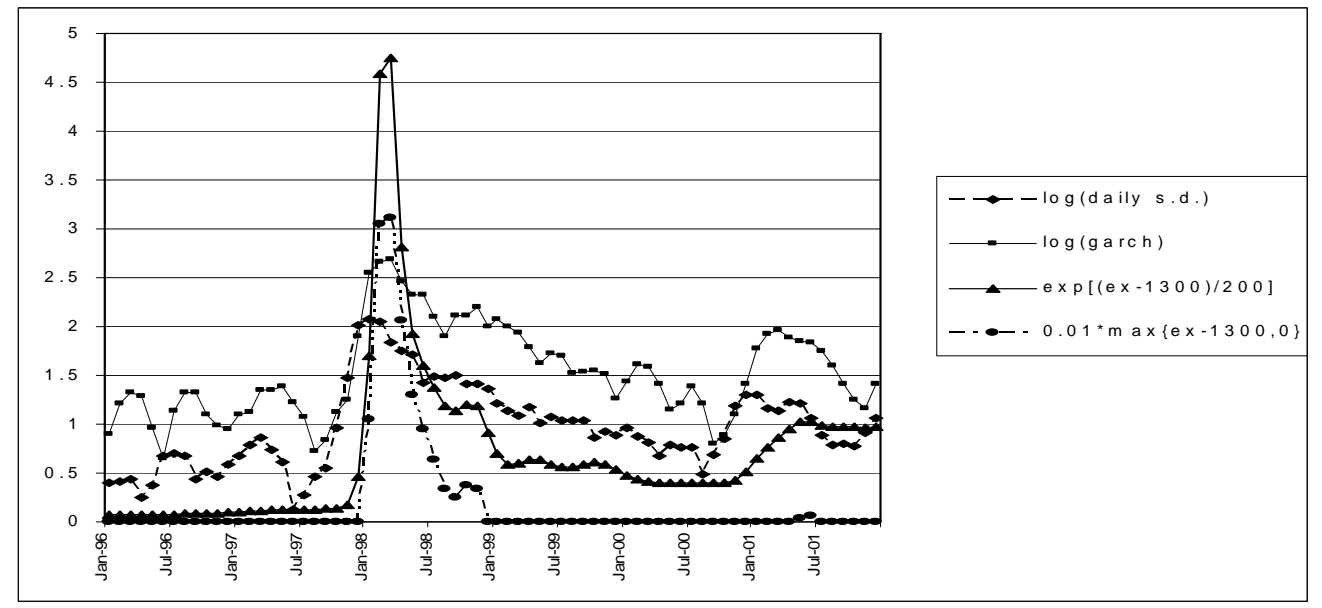

During the Asian financial crisis, the Korean won lost about half its value against the U.S. dollar within two months and rebounded steadily in the next three years. On December 3, 1997, in agreement with the IMF the Central Bank of Korea is instructed to support the won whenever the won/dollar rate goes above $1300 .{ }^{16} \mathrm{~A}$ won/dollar rate of 1300 was seen as representing a substantial devaluation and values in excess of 1300 were viewed as excessive relative to the 800 to 900 levels that had prevailed over several years prior to November 1997. The won/dollar rate exceeded 1300 on December 8, 1997 and would not fall below 1300 again until July 7, 1998. To provide further robustness checks of our results we will use two additional indicators of uncertainty beside $L($ sdex $)$ and $L($ garch $)$. Additional monthly measures of volatility are given by $V(\exp ) \equiv e^{\{(e x-1300) / 200\}}$ and $V(\max ) \equiv 0.01 \max \{e x-1300,0\}$. The first measure of

\footnotetext{
15 A survey of measures of exchange rate volatility used in the FDI literature can be found in Kiyota and Urata (2004). Campa (1993) measures exchange rate volatility as the standard deviation of monthly change in the logarithm of the exchange rate. Goldberg and Kolstad (1995) measure exchange rate volatility as the normalized standard deviation of twelve quarters of the real exchange rate prior to and inclusive of the current quarter. Cushman (1985) introduces the average level of "surprise" as a measure of uncertainty given by the deviation of the currently observed real exchange rate from that expected, in addition to measuring volatility in the exchange rate by the standard deviation of quarterly changes in the real exchange rate within the current year.
}

16 During the Asian crisis the IMF set target levels for the exchange rate and Korean interest rates were to be raised whenever the won/dollar rate exceeded 1300 . 
uncertainty captures a non-linearity, in that deviations of the exchange rate from 1300 indicate proportionately greater uncertainty than indicated by the amount ex exceeds 1300 , and the second measure of uncertainty captures a non-linearity confined mostly to the period of the financial crisis. These measures of exchange rate volatility are shown in Figure 3.

A capital control index, $c c$, set at zero up through 1998:10 and set at 1 after 1998:10, is included in $X_{t}$. In order to isolate the effect of relaxation of capital controls from the crisis period negative binomial and binomial logit regressions will be reported for 1996:1-1998:10 and for 1996:1-2001:12. For the latter period the capital control index, $c c$, will be introduced as an explanatory variable.

\subsubsection{FDI Counts}

MLE estimates of $(\beta, \delta)$ in negative binomial regressions are obtained and reported for count of FDI by investor and host firm by experience and size in the Tables 4A, 4B and 4C. For the explanatory variables that are in logarithm, the estimates can be interpreted as an approximation of elasticity of the expected FDI counts with respect to the explanatory variables.

In Table 4A negative binomial regressions are reported for 1996:1-1998:10. Regressions for total count of FDI, for count of FDI by investors with no experience, for count of FDI by investors with paired experience (the investor and host firm have prior FDI with each other implying that FDI is a second or subsequent FDI), and for count of large FDI (FDI over one million dollars) by investors with paired experience are labeled (i)-(iii), (iv)-(vi), (vii)-(ix), and (x)-(xii). A dummy variable to capture the financial crisis, Crisis, set at 1 over 1997:11-1998:7, and zero otherwise, has a positive coefficient that is statistically significant at the $10 \%$ level of confidence for count of FDI for all agents. The coefficient of Crisis is not statistically significant for count of FDI by investors with no experience and is positive and statistically significant at the $1 \%$ level of confidence for count of FDI by investors with paired experience and is. The coefficient on Crisis is greatest for large FDI by experienced investors, a group likely to have the greatest information on investment prospects.

The exchange rate (Lex, the logarithm of ex) has a statistically significant positive coefficient in regression (ii) in Table 4A. This result suggests that a devaluation of $10 \%$ leads to a $3.7 \%$ increase in total FDI count. In contrast, a $10 \%$ devaluation leads to a $5.3 \%$ rise in FDI count by investors with paired experience (regression (viii)) and to a $10.4 \%$ increase in the count of large FDI by investors with paired experience (regression (xi)). Uncertainty about the exchange rate $(L(s d e x))$ also significantly raises FDI count by investors with paired experience with a more marked effect for large FDI within this group (from regressions (ix) and (xii)). ${ }^{17}$ Lex and $L(s d e x$ ) are not statistically significant in the regressions for FDI by inexperienced investors.

Note that given the strong correlation between exchange rate and exchange rate uncertainty during the sample period, they are two sides of the same token of the crisis. Our answer to Krugman's (1998) question regarding the general pattern of FDI after financial crisis "why should direct investment surge at a time when foreign capital in

17 Lex and $L(s d e x)$ are positively correlated and their appearance in the same regression results in imprecise estimates with neither variable being statistically significant. These results are not reported. 
general is fleeing a country?" is that crisis afford investors low prices of potentially productive assets. Informed investors of FDI tend be able to seize the opportunity better than others. Among the FDI investors, those with more knowledge of the host firms are more likely to rush in at the time when uncertainty is high and asset price is low. The positive coefficient of volatility in Table 3 should not be interpreted as uncertainty raises investment from experienced investors, it should be interpreted as investment from experienced investors increases despite high macro uncertainty because of their relatively low overall uncertainty (at micro and macro level). For inexperienced investors, the attractive asset price during crisis is largely offset by the heightened uncertainty. Hence they are less willing to invest during crisis.

Table 4A. Negative Binominal Results: Monthly FDI Count by Investors with Different Information: 1996:1-1998:10

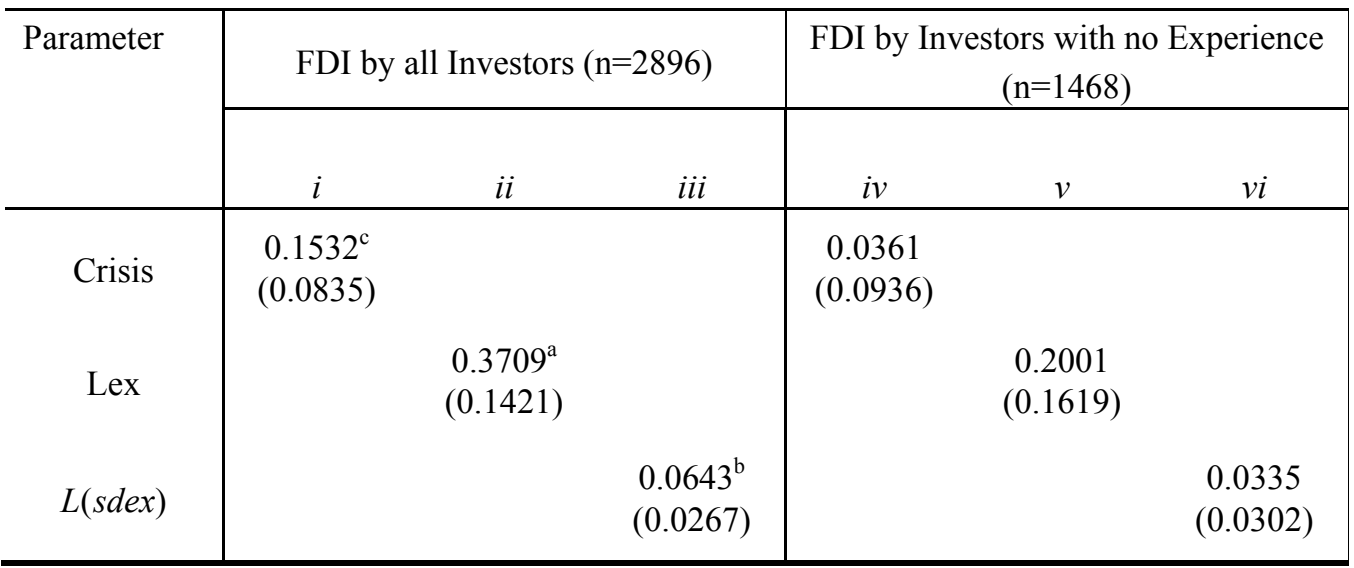

\begin{tabular}{|c|c|c|c|c|c|c|}
\hline \multirow[t]{2}{*}{ Parameter } & \multicolumn{3}{|c|}{$\begin{array}{l}\text { FDI by Investors with paired } \\
\text { experience } \\
(n=1091)\end{array}$} & \multicolumn{3}{|c|}{$\begin{array}{l}\text { Large FDI by Investors with paired } \\
\text { experience } \\
\qquad(\mathrm{n}=445)\end{array}$} \\
\hline & $v i i$ & viii & $i x$ & $x$ & $x i$ & $x i i$ \\
\hline Crisis & $\begin{array}{r}0.2716 \\
(0.098\end{array}$ & & & $\begin{array}{c}0.4541^{\mathrm{a}} \\
(0.1351)\end{array}$ & & \\
\hline Lex & \multicolumn{3}{|c|}{$\begin{array}{c}0.5338^{\mathrm{a}} \\
(0.1724)\end{array}$} & \multicolumn{3}{|c|}{$\begin{array}{c}1.0361^{\mathrm{a}} \\
(0.2154)\end{array}$} \\
\hline$L($ sdex $)$ & & & $\begin{array}{c}0.0979^{\mathrm{a}} \\
(0.0320)\end{array}$ & & & $\begin{array}{c}0.1855^{\mathrm{a}} \\
(0.0433)\end{array}$ \\
\hline
\end{tabular}

Notes: Investors with paired experience refers to investor and host firm having FDI experience with each other prior to current FDI event. FDI by investors with no experience is first-time FDI by investors. Large FDI is FDI greater than or equal to $\$ 1$ million. Crisis=index for financial crisis set at 1 over 1997:11-1998:7 and zero otherwise; Lex= log of 3-month moving average of exchange rate (won per dollar) centered on preceding month; Volatility- $L($ sdex $)=$ the $\log$ of the of 3-month moving average of standard deviation of the daily change in the won/dollar exchange rate each month centered on the preceding month; Standard errors are given in parenthesis. Superscripts a, b, and $\mathrm{c}$ indicate significance level of at least $1 \%, 5 \%$, and $10 \%$, respectively. 
In Table 4B we report negative binominal regression results for monthly FDI count over 1996:1-1998:10 for the same groups as in Table 4A, but for different measures of volatility of the exchange rate. The result that large value FDI by experienced investors has a relatively large statistically significant positive response to increased volatility of the exchange rate, whereas inexperienced investors do not have a statistically significant response is robust across the alternative measures volatility.

In Table 4C we report negative binominal regression results for monthly FDI count over 1996:1-2001:12 for the two groups appearing in Table 4A that had the most divergent results, i.e., for the count of large FDI by investors with paired experience and count of FDI by investors with no experience. In the regression equations in Table 4C a capital control dummy is introduced to control for the change in capital control regime in November 1998. A positive value for cc indicates a relaxation of capital control. For the most part a relaxation of capital control resulted in a statistically significant increase in FDI count of both large FDI by investors with paired experience and FDI by inexperienced investors, but the coefficient for the inexperienced investors is of the order of 5 times as big as that for the count of large FDI by experienced pairs. The

Table 4B. Negative Binominal Results: Monthly FDI Count by Investors with Different Information for Different Measures of Volatility of Exchange Rates: 1996:1-1998:10

\begin{tabular}{|c|c|c|c|c|c|c|}
\hline \multirow[t]{3}{*}{ Parameter } & \multicolumn{3}{|c|}{ FDI by all Investors ( $\mathrm{n}=2896)$} & \multicolumn{3}{|c|}{$\begin{array}{l}\text { FDI by Investors with no Experience } \\
\qquad(n=1468)\end{array}$} \\
\hline & $\begin{array}{l}\text { Volatility }= \\
L(\text { garch })\end{array}$ & $\begin{array}{l}\text { Volatility } \\
=V(\exp )\end{array}$ & $\begin{array}{l}\text { Volatility } \\
=V(\max )\end{array}$ & $\begin{array}{l}\text { Volatility }= \\
L(\text { garch })\end{array}$ & $\begin{array}{c}\text { Volatility }= \\
V(\exp )\end{array}$ & $\begin{array}{c}\text { Volatility }= \\
V(\max )\end{array}$ \\
\hline & $i$ & $i i$ & $i i i$ & $i v$ & $v$ & $v i$ \\
\hline Volatility & $\begin{array}{l}0.0578^{\mathrm{b}} \\
(0.0271)\end{array}$ & $\begin{array}{c}0.0513 \\
(0.0321)\end{array}$ & $\begin{array}{c}0.0638 \\
(0.0470)\end{array}$ & $\begin{array}{c}0.0322 \\
(0.0303)\end{array}$ & $\begin{array}{c}0.0218 \\
(0.0349)\end{array}$ & $\begin{array}{c}0.0205 \\
(0.0509)\end{array}$ \\
\hline
\end{tabular}

\begin{tabular}{|c|c|c|c|c|c|c|}
\hline \multirow[t]{3}{*}{ Parameter } & \multicolumn{3}{|c|}{$\begin{array}{c}\text { FDI by Investors with paired } \\
\text { experience }(n=1091)\end{array}$} & \multicolumn{3}{|c|}{$\begin{array}{l}\text { Large FDI by Investors with paired } \\
\text { experience }(\mathrm{n}=445)\end{array}$} \\
\hline & $\begin{array}{c}\text { Volatility }= \\
L(\text { garch })\end{array}$ & $\begin{array}{l}\text { Volatility } \\
=V(\exp )\end{array}$ & $\begin{array}{l}\text { Volatility } \\
=V(\max )\end{array}$ & $\begin{array}{c}\text { Volatility }= \\
L(\text { garch })\end{array}$ & $\begin{array}{c}\text { Volatility }= \\
V(\exp )\end{array}$ & $\begin{array}{l}\text { Volatility }= \\
V(\max )\end{array}$ \\
\hline & $v i i$ & viii & $i x$ & $x$ & $x i$ & $x i i$ \\
\hline Volatility & $\begin{array}{l}0.0801^{\mathrm{a}} \\
(0.0334)\end{array}$ & $\begin{array}{l}0.0775^{\mathrm{b}} \\
(0.0334)\end{array}$ & $\begin{array}{l}0.1038^{c} \\
(0.0571)\end{array}$ & $\begin{array}{l}0.1684^{\mathrm{a}} \\
(0.0449)\end{array}$ & $\begin{array}{l}0.1402^{\mathrm{a}} \\
(0.0558)\end{array}$ & $\begin{array}{c}0.1770^{b} \\
(0.0823)\end{array}$ \\
\hline
\end{tabular}

Notes: Investors with paired experience refers to investor and host firm having FDI experience with each other prior to current FDI event. FDI by agents with no experience is first-time FDI by agents. Large FDI is FDI greater than or equal to $\$ 1$ million. Volatility- $L($ garch $)=\log$ of 3-month moving average of monthly exchange rate volatility given by the conditional standard deviation generated by a GARCH process fitted to the exchange rate, centered on preceding month; Volatility is also measured alternatively by $V(\max )=0.01 \max \{e x-1300,0\}$ and by $V(\exp )=e^{\{(e x-1300) / 200\}}$, where $e x$ is 3-month moving average won/dollar exchange rate. Standard errors are given in parenthesis. Superscripts $\mathrm{a}, \mathrm{b}$, and $\mathrm{c}$ indicate significance level of at least $1 \%, 5 \%$, and $10 \%$, respectively. 
Table 4C. Negative Binominal Results: Monthly FDI Count by Investors with Different Information: 1996:1-2001:12

\begin{tabular}{|c|c|c|c|c|c|c|}
\hline \multirow[t]{3}{*}{ Parameter } & \multicolumn{6}{|c|}{ Large FDI by Investors with paired experience $(n=1041)$} \\
\hline & & & $\begin{array}{c}\text { Volatility }= \\
L(\text { sdex })\end{array}$ & $\begin{array}{c}\text { Volatility }= \\
L(\text { garch })\end{array}$ & $\begin{array}{c}\text { Volatility }= \\
V(\exp )\end{array}$ & $\begin{array}{c}\text { Volatility }= \\
V(\max )\end{array}$ \\
\hline & $v i i$ & viii & $i x$ & $x$ & $x i$ & $x i i$ \\
\hline Crisis & $\begin{array}{c}0.2474^{b} \\
(0.1202)\end{array}$ & & & & & \\
\hline Lex & & $\begin{array}{c}0.9343^{\mathrm{a}} \\
(0.2094)\end{array}$ & & & & \\
\hline Volatility & & & $\begin{array}{c}0.1701^{\mathrm{a}} \\
(0.0377)\end{array}$ & $\begin{array}{c}0.1135^{\mathrm{a}} \\
(0.0370)\end{array}$ & $\begin{array}{c}0.1703^{b} \\
(0.0701)\end{array}$ & $\begin{array}{c}0.1251^{\mathrm{a}} \\
(0.0471)\end{array}$ \\
\hline $\mathrm{cc}$ & & $\begin{array}{c}0.0272 \\
(0.0813)\end{array}$ & $\begin{array}{c}0.1885^{\mathrm{b}} \\
(0.0747)\end{array}$ & $\begin{array}{c}0.1844^{b} \\
(0.0793)\end{array}$ & $\begin{array}{c}0.2549^{\mathrm{a}} \\
(0.0866)\end{array}$ & $\begin{array}{c}0.2020^{\mathrm{b}} \\
(0.0809)\end{array}$ \\
\hline
\end{tabular}

\begin{tabular}{|c|c|c|c|c|c|c|}
\hline \multirow[t]{3}{*}{ Parameter } & \multicolumn{6}{|c|}{ FDI by Investors with no Experience $(\mathrm{n}=6137)$} \\
\hline & & & $\begin{array}{c}\text { Volatility }= \\
L(\text { sdex })\end{array}$ & $\begin{array}{c}\text { Volatility }= \\
L(\text { garch })\end{array}$ & $\begin{array}{c}\text { Volatility }= \\
V(\exp )\end{array}$ & $\begin{array}{c}\text { Volatility }= \\
V(\max )\end{array}$ \\
\hline & $v i i$ & viii & $i x$ & $x$ & $x i$ & $x i i$ \\
\hline Crisis & $\begin{array}{l}-0.7200^{\mathrm{a}} \\
(0.2039)\end{array}$ & & & & & \\
\hline Lex & & $\begin{array}{c}-0.0103 \\
(0.2416)\end{array}$ & & & & \\
\hline Volatility & & & $\begin{array}{c}-0.0111 \\
(0.0377)\end{array}$ & $\begin{array}{l}-0.0306 \\
(0.0395)\end{array}$ & $\begin{array}{c}0.0128 \\
(0.0778)\end{array}$ & $\begin{array}{c}-0.0090 \\
(0.0514)\end{array}$ \\
\hline $\mathrm{cc}$ & & $\begin{array}{r}1.0476^{\mathrm{a}} \\
(0.0947)\end{array}$ & $\begin{array}{r}1.0457^{\mathrm{a}} \\
(0.0846)\end{array}$ & $\begin{array}{r}1.0444^{\mathrm{a}} \\
(0.0842)\end{array}$ & $\begin{array}{r}1.0508^{\mathrm{a}} \\
(0.0897)\end{array}$ & $\begin{array}{c}1.0446^{\mathrm{a}} \\
(0.0849)\end{array}$ \\
\hline
\end{tabular}

Notes: Investors with paired experience refers to investor and host firm having FDI experience with each other prior to current FDI event. FDI by investors with no experience is first-time FDI by investors. Large FDI is FDI greater than or equal to $\$ 1$ million. Crisis=index for financial crisis set at 1 over 1997:11-1998:7 and zero otherwise; Lex = log of 3-month moving average of exchange rate (won per dollar) centered on preceding month; Volatility- $L(s d e x)=$ the $\log$ of the of 3-month moving average of standard deviation of the daily change in the won/dollar exchange rate each month centered on the preceding month; Standard errors are given in parenthesis. Volatility$L($ garch $)=\log$ of 3-month moving average of monthly exchange rate volatility given by the conditional standard deviation generated by a GARCH process fitted to the exchange rate, centered on preceding month; Volatility is also measured alternatively by $V(\max )=0.01 \max \{e x-1300,0\}$ and by $V(\exp )=e^{\{(e x-1300) / 200\}}$, where $e x$ is 3-month moving average won/dollar exchange rate. $\mathrm{cc}=$ index of capital control set at zero prior to 1998:11, and set at 1 after 1998:11. Superscripts a, b, and $\mathrm{c}$ indicate significance level of at least $1 \%, 5 \%$, and $10 \%$, respectively. 
results in Table 4C for the effect of devaluation and exchange rate volatility on count of FDI over 1996:1-2001:12 are very similar to those found in the Tables 4A and 4B over 1996:1-1998:10. We find that over the period 1996:1-2001:12 large FDI by experienced investors has a statistically significant positive response to devaluation and to increased volatility of the exchange rate, but FDI by inexperienced investors does not.

\subsection{Modeling Likelihood of FDI: Binomial Logit Regression Model}

In this section we will examine the impact of the exchange rate on the relative likelihood of different categories of experience of FDI with a binomial logit regression. This analysis will supplement that obtained from the negative binomial regressions on the effect of investor information on the connection between the exchange rate and FDI by allowing for the introduction of individual characteristics of size of FDI and whether the host firm is foreign or domestically owned.

We note that a binomial logit model gives probability that each case is true among a set of mutually exclusive scenarios, conditioning on a set of observed control variables. Although binomial logit is commonly used to model discrete choice of economic agents, such a behavioral interpretation is not intrinsically related to the model. The interpretation of the estimated conditional probabilities in this study is not about an investor's choice of being 'experienced' or 'inexperienced'. Instead, the estimates we present will capture the probability of a given incident of FDI falling into a particular category, conditional on macroeconomic variables and other the control variables. The 'reduced form' interpretation of the binomial logit means that the Independence from Irrelevant Alternatives (IIA) property (the ratio of the conditional probabilities of two categories is independent of other categories) is plausible.

For a binomial logit model, let the dummy variables $d_{j}=1,2$ identify mutually exclusive and exhaustive categories of FDI. The likelihood of the type of FDI $D=\left(d_{1}, d_{2}\right)$ is given by binomial distribution, $\prod_{t=1}^{T} \prod_{j=1}^{2} p_{j t}^{D_{t j}}$, where $D_{j t}=1$ if $d_{j}=1$ and $D_{j t}=0$, otherwise. The probability $p_{j t}$ is characterized by a logit model $p_{1 t}=\exp \left(z_{t}^{\prime} \phi\right) /\left\{1+\exp \left(z_{t}^{\prime} \phi\right)\right\}$ and default normalization $p_{2 t}=1 /\left\{1+\exp \left(z_{t}^{\prime} \phi\right)\right\}$, where $z_{t}$ is a vector of economic factors that determine the probabilities $p_{j t},(j=1,2)$. By construction the logarithm of probability of FDI of type 1 over that of type 2 is given by $\log \left(p_{1 t} / p_{2 t}\right)=z_{t}^{\prime} \phi$.

\subsubsection{Microeconomic variables}

Existing unlisted (majority owned) domestic firms are probably more likely to be open to potential inexperienced investors than are existing unlisted foreign (owned) firms. The influence on the probability that an FDI made to a domestic firm is by an experienced investor or not is recognized by introducing an indicator of type of host firm, Domestic, with Domestic $=1$ if the FDI host is an unlisted domestic firm, and 0 otherwise, into the vector $z_{t}$. Similarly, the log of size of individual FDI, Lsize, is also introduced into the vector of economic factors $z_{t}$. 


\subsubsection{Likelihood of FDI by Information}

We will consider two categories of FDI that differ with regard to agent experience. ${ }^{18}$ These categories are: $d_{1}=1$ if FDI is by investors with paired experience (investor and host firm have at least one FDI experience before time t) and 0 otherwise, and $d_{2}=1$ for all other FDI and 0 otherwise. Binomial logit regressions of the probability of whether FDI is more likely to be by investors with paired experience rather than by all other investors (the default category) are reported in the Tables 5A and 5B.

In Table 5A binomial logit regressions (i)-(iv) and (v)-(viii) are reported for 1996:11998:10 and for 1996:1-2001:12, respectively. The results indicate that with devaluation or a rise in exchange rate uncertainty, FDI is significantly more likely to be FDI by investors with paired experience relative to FDI by other investors, even when controlling for size of individual FDI and ownership of host firm. Thus, the results from the binomial regressions are consistent with those from the negative binomial regressions that experienced investors are more sensitive to high exchange rate volatility. The absence of FDI by inexperienced investors during the crisis, particularly as indicated in regressions (i)-(iv) in Table 5A for 1996:1-1998:10, a period preceding the relaxation of capital controls, indicates that there is a very high cost in searching and evaluating host firms.

In Table 5A, the log of size of individual FDI and the indicator of type of host firm are statistically significant. If an FDI is of large size, then it is significantly more likely to be associated with agents with paired experience. As expected, if an FDI involves a host that is a domestic firm then it is significantly more likely to be by an inexperienced investor. An alternative way of stating this result is that if FDI involves a host firm that is foreign owned, then it is significantly more likely to involve investors with paired experience. Put in this way, the finding is consistent with the observation by Lipsey (2001) that FDI is a relatively stable investment flow during crisis, and that experienced investors in foreign-owned firms make use of investment opportunities that allow them to grow rapidly. 19 FDI prompted by investors' information makes a valuable contribution to recovery from crisis.

In regressions (v)-(viii) in Table 5A, relaxation of capital control is found, as expected, to make it much more likely that FDI is by inexperienced agents. As the crisis passes, new and inexperienced investors attracted by a favorable exchange rate and easing of capital control start to accumulate in the Korean market. In Table 5B the results in Table 5A are found to be robust across different measures of exchange rate volatility.

\footnotetext{
18 The groups are always mutually exclusive and exhaustive. Groups could be further subdivided into paired experience and the cases of an FDI involving experienced investors and inexperienced host firms, inexperienced investors and experienced host firms, no experience FDI. Not much is gained by this division that would come at the cost of adding more detail to the Tables 5A and 5B.
}

19 New FDI is provided over 1997:11-1998:7, even though the premium for liquidity measured by the Korean short-term interest rate jumped from about 13\% in November 1997 to $23 \%$ in December 1997 , and fell back to $12 \%$ only in July 1998. At the high premium there was evidence that liquidity was available. Borensztein and Lee (2002) with firm level data for Korea find no credit contraction in the first half of 1998. They find that total bank borrowing increased both in absolute terms and relative to other forms of finance for the average firm over the first half of 1998. 
Table 5A. Binomial Logit Regressions: Likelihood of FDI by Investors with More Information: 1996:1-1998:10 \& 1996:1-2001:12

Dependent variable 1: FDI by Investors with paired experience.

Dependent variable 2 (the default): All other FDI.

\begin{tabular}{|c|c|c|c|c|}
\hline \multirow[t]{2}{*}{ Parameter } & \multicolumn{4}{|c|}{$\begin{array}{l}\qquad 1996: 1-1998: 10 \\
\text { FDI by Investors with paired experience (second and subsequent FDI) }\end{array}$} \\
\hline & $i$ & $i i$ & $i i i$ & $i v$ \\
\hline Lex & & $\begin{array}{l}0.0130^{c} \\
(0.0075)\end{array}$ & & $\begin{array}{l}-0.0091 \\
(0.0131)\end{array}$ \\
\hline$L($ sdex $)$ & & & $\begin{array}{l}0.0471^{\mathrm{a}} \\
(0.0182)\end{array}$ & $\begin{array}{l}0.0649^{b} \\
(0.0293)\end{array}$ \\
\hline Lsize & $\begin{array}{l}0.2628^{\mathrm{a}} \\
(0.0204)\end{array}$ & $\begin{array}{l}0.2761^{\mathrm{a}} \\
(0.0219)\end{array}$ & $\begin{array}{l}0.2790^{\mathrm{a}} \\
(0.0214)\end{array}$ & $\begin{array}{l}0.2758^{\mathrm{a}} \\
(0.0219)\end{array}$ \\
\hline Domestic & $\begin{array}{l}-0.8545^{\mathrm{a}} \\
(0.0762)\end{array}$ & $\begin{array}{l}-0.9310^{\mathrm{a}} \\
(0.0882)\end{array}$ & $\begin{array}{l}-0.9458^{a} \\
(0.0842)\end{array}$ & $\begin{array}{l}-0.9275^{\mathrm{a}} \\
(0.0883)\end{array}$ \\
\hline
\end{tabular}

\begin{tabular}{|c|c|c|c|c|}
\hline \multirow[t]{2}{*}{ Parameter } & \multicolumn{4}{|c|}{$\begin{array}{l}1996: 1-2001: 12 \\
\text { FDI by Investors with paired experience (second and subsequent FDI) }\end{array}$} \\
\hline & $v$ & $v i$ & $v i i$ & viii \\
\hline Lex & & $\begin{array}{l}0.0310^{\mathrm{a}} \\
(0.0066)\end{array}$ & & $\begin{array}{l}-0.0001 \\
(0.0120)\end{array}$ \\
\hline$L(\operatorname{sdex})$ & & & $\begin{array}{l}0.0911^{\mathrm{a}} \\
(0.0162)\end{array}$ & $\begin{array}{l}0.0913^{\mathrm{a}} \\
(0.0293)\end{array}$ \\
\hline $\mathrm{Cc}$ & $\begin{array}{l}-0.4882^{\mathrm{a}} \\
(0.0419)\end{array}$ & $\begin{array}{l}-0.6567^{\mathrm{a}} \\
(0.0549)\end{array}$ & $\begin{array}{l}-0.6458^{\mathrm{a}} \\
(0.0500)\end{array}$ & $\begin{array}{l}-0.6456^{\mathrm{a}} \\
(0.0550)\end{array}$ \\
\hline Lsize & $\begin{array}{l}0.3546^{\mathrm{a}} \\
(0.0128)\end{array}$ & $\begin{array}{l}0.3668^{\mathrm{a}} \\
(0.0128)\end{array}$ & $\begin{array}{l}0.3664^{\mathrm{a}} \\
(0.0127)\end{array}$ & $\begin{array}{l}0.3664^{\mathrm{a}} \\
(0.0128)\end{array}$ \\
\hline Domestic & $\begin{array}{l}-0.9856^{\mathrm{a}} \\
(0.0514)\end{array}$ & $\begin{array}{l}-1.0661^{a} \\
(0.0540)\end{array}$ & $\begin{array}{l}-1.0604^{\mathrm{a}} \\
(0.0529)\end{array}$ & $\begin{array}{l}-1.0603^{\mathrm{a}} \\
(0.0540)\end{array}$ \\
\hline
\end{tabular}

Notes: Investors with paired experience refers to investor and host firm having FDI experience with each other prior to current FDI event. Lex $=\log$ of 3-month moving average of exchange rate (won per dollar) centered on preceding month; Volatility- $L(s d e x)=$ the $\log$ of the of 3-month moving average of standard deviation of the daily change in the won/dollar exchange rate each month centered on the preceding month; $\mathrm{cc}=$ index of capital control set at zero prior to 1998:11, and set at 1 after 1998:11; Lsize = the log of size of individual FDI; Domestic $=1$ if the FDI host is an unlisted domestic firm, and 0 otherwise;. Standard errors are given in parenthesis. Superscripts a, b, and c indicate significance level of at least $1 \%, 5 \%$, and $10 \%$, respectively. 
Table 5B. Binomial Logit Regressions: Likelihood of FDI by Investors with More Information for Different Measures of Volatility: 1996:1-1998:10 \& 1996:1-2001:12

Dependent variable 1: FDI by Investors with paired experience.

Dependent variable 2 (the default): All other FDI.

\begin{tabular}{|c|c|c|c|c|c|c|}
\hline \multirow[t]{3}{*}{ Parameter } & \multicolumn{6}{|c|}{$\begin{array}{l}\qquad 1996: 1-1998: 10 \\
\text { FDI by Investors with paired experience (second and subsequent FDI) }\end{array}$} \\
\hline & \multicolumn{2}{|c|}{$\begin{array}{l}\text { Volatility }= \\
L(\text { garch })\end{array}$} & \multicolumn{2}{|c|}{ Volatility $=V(\exp )$} & \multicolumn{2}{|c|}{ Volatility $=V(\max )$} \\
\hline & $i$ & $i i$ & $i i i$ & $i v$ & $v$ & $v i$ \\
\hline Lex & & $\begin{array}{l}-0.0161 \\
(0.0185)\end{array}$ & & $\begin{array}{c}0.0064 \\
(0.0082)\end{array}$ & & $\begin{array}{c}0.0044 \\
(0.0086)\end{array}$ \\
\hline Volatility & $\begin{array}{l}0.0303^{b} \\
(0.0133)\end{array}$ & $\begin{array}{l}0.0564^{\mathrm{c}} \\
(0.0327)\end{array}$ & $\begin{array}{l}0.1195^{\mathrm{a}} \\
(0.0453)\end{array}$ & $\begin{array}{l}0.1050^{b} \\
(0.0491)\end{array}$ & $\begin{array}{l}0.0804^{\mathrm{a}} \\
(0.0341)\end{array}$ & $\begin{array}{l}0.0721^{\mathrm{b}} \\
(0.0341)\end{array}$ \\
\hline Lsize & $\begin{array}{l}0.2791^{\mathrm{a}} \\
(0.0217)\end{array}$ & $\begin{array}{l}0.2765^{\mathrm{a}} \\
(0.0219)\end{array}$ & $\begin{array}{l}0.2718^{\mathrm{a}} \\
(0.0207)\end{array}$ & $\begin{array}{c}0.2772^{\mathrm{a}} \\
(0.0219)\end{array}$ & $\begin{array}{c}0.2737^{\mathrm{a}} \\
(0.0219)\end{array}$ & $\begin{array}{c}0.2771^{\mathrm{a}} \\
(0.0219)\end{array}$ \\
\hline Domestic & $\begin{array}{l}-0.9454^{\mathrm{a}} \\
(0.0862)\end{array}$ & $\begin{array}{l}-0.9289^{a} \\
(0.0883)\end{array}$ & $\begin{array}{l}-0.8892^{a} \\
(0.0783)\end{array}$ & $\begin{array}{l}-0.9310^{a} \\
(0.0883)\end{array}$ & $\begin{array}{l}-0.9110^{\mathrm{a}} \\
(0.0794)\end{array}$ & $\begin{array}{l}-0.9309^{a} \\
(0.0883)\end{array}$ \\
\hline
\end{tabular}

\begin{tabular}{|c|c|c|c|c|c|c|}
\hline \multirow[t]{3}{*}{ Parameter } & \multicolumn{6}{|c|}{$\begin{array}{l}1996: 1-2001: 12 \\
\text { FDI by Investors with paired experience (second and subsequent FDI) }\end{array}$} \\
\hline & \multicolumn{2}{|c|}{$\begin{array}{l}\text { Volatility }= \\
L(\text { garch })\end{array}$} & \multicolumn{2}{|c|}{ Volatility $=V(\exp )$} & \multicolumn{2}{|c|}{ Volatility $=V(\max )$} \\
\hline & $v i i$ & viii & $i x$ & $x$ & $x i$ & $x i i$ \\
\hline Lex & & $\begin{array}{l}-0.0100 \\
(0.0156)\end{array}$ & & $\begin{array}{l}0.0165^{\mathrm{b}} \\
(0.0078)\end{array}$ & & $\begin{array}{l}0.0239^{\mathrm{a}} \\
(0.0074)\end{array}$ \\
\hline Volatility & $\begin{array}{l}0.0631^{\mathrm{a}} \\
(0.0115)\end{array}$ & $\begin{array}{l}0.0788^{\mathrm{a}} \\
(0.0273)\end{array}$ & $\begin{array}{l}0.1581^{\mathrm{a}} \\
(0.0287)\end{array}$ & $\begin{array}{l}0.1201^{\mathrm{a}} \\
(0.0340)\end{array}$ & $\begin{array}{l}0.1828^{\mathrm{a}} \\
(0.0506)\end{array}$ & $\begin{array}{l}0.1101^{\mathrm{b}} \\
(0.0506)\end{array}$ \\
\hline $\mathrm{cc}$ & $\begin{array}{l}-0.6559^{\mathrm{a}} \\
(0.0516)\end{array}$ & $\begin{array}{l}-0.6436^{\mathrm{a}} \\
(0.0551)\end{array}$ & $\begin{array}{l}-0.5594^{\mathrm{a}} \\
(0.0436)\end{array}$ & $\begin{array}{l}-0.6321^{\mathrm{a}} \\
(0.0554)\end{array}$ & $\begin{array}{l}-0.4700^{\mathrm{a}} \\
(0.0421)\end{array}$ & $\begin{array}{l}-0.6078^{a} \\
(0.0595)\end{array}$ \\
\hline Lsize & $\begin{array}{c}0.3677^{\mathrm{a}} \\
(0.0128)\end{array}$ & $\begin{array}{c}0.3671^{\mathrm{a}} \\
(0.0128)\end{array}$ & $\begin{array}{c}0.3632^{\mathrm{a}} \\
(0.0127)\end{array}$ & $\begin{array}{c}0.3676^{\mathrm{a}} \\
(0.0128)\end{array}$ & $\begin{array}{c}0.3597^{\mathrm{a}} \\
(0.0126)\end{array}$ & $\begin{array}{c}0.3671^{\mathrm{a}} \\
(0.0128)\end{array}$ \\
\hline Domestic & $\begin{array}{l}-1.0659^{a} \\
(0.0533)\end{array}$ & $\begin{array}{l}-1.0602^{\mathrm{a}} \\
(0.0540)\end{array}$ & $\begin{array}{l}-1.0336^{\mathrm{a}} \\
(0.0521)\end{array}$ & $\begin{array}{l}-1.0644^{\mathrm{a}} \\
(0.0540)\end{array}$ & $\begin{array}{l}-1.0157^{\mathrm{a}} \\
(0.0519)\end{array}$ & $\begin{array}{l}-1.0657^{\mathrm{a}} \\
(0.0540)\end{array}$ \\
\hline
\end{tabular}

Notes: Investors with paired experience refers to investor and host firm having FDI experience with each other prior to current FDI event. Lex= log of 3-month moving average of exchange rate (won per dollar) centered on preceding month; Volatility- $L$ (garch) $=\log$ of 3-month moving average of monthly exchange rate volatility given by the conditional standard deviation generated by a GARCH process fitted to the exchange rate, centered on preceding month; $V(\max )=0.01 \max \{e x-1300,0\}$ and by $V(\exp )=e^{\{(e x-1300) / 200\}}$, where $e x$ is 3-month moving average won/dollar exchange rate; $\mathrm{cc}=$ index of capital control set at zero prior to 1998:11, and set at 1 after 1998:11; Lsize $=$ the $\log$ of size of individual FDI; Domestic $=1$ if the FDI host is an unlisted domestic firm, and 0 otherwise; Standard errors are given in parenthesis. Superscripts a, b, and c indicate significance level of at least $1 \%, 5 \%$, and $10 \%$, respectively. 
The default category in the Tables $5 \mathrm{~A}$ and 5B, FDI by investors who are not investors with paired experience, is overwhelmingly first-time FDI by investors. From those making first-time FDI, ex post examination of data on first-time FDI by investors enables identification of those making one-time FDI and those who go on to become investors with paired experience by making subsequent FDI. In regression analysis not reported in the tables, we find that these two investor groups making first-time FDI do not react in different ways to the exchange rate. The results show devaluation is much more likely to result in FDI by investors with paired experience than by investors making FDI for the first-time, whether by investors who will eventually become experienced or by investors who will not participate in FDI again. However, results indicate that first-time FDI by what will become an investor with paired experience compared to first-time FDI that will turn out to be only one-shot FDI is likely to be significantly larger, more likely to establish a foreign-owned firm, and less likely when capital controls are relaxed.

The negative binomial counts regressions and the binomial logit regressions results can be summarized as follows: investor information (indicated by experience and size of FDI) influences response to macroeconomic uncertainty indicated by volatility in the exchange rate; and capital controls are important regulatory barriers that keep relatively small inexperienced investors out of the domestic market and that policies to reduce the cost of finding an investor-host match could be a cost effective way of facilitating FDI.

\section{Conclusion}

In the model of investment under uncertainty with Bayesian updating presented in this paper, investors with different information take different courses of action with regard to investment. We argue that in situations in which there is a sudden change in environment, subjective uncertainty (about the model) is likely to be substantially and unevenly increased across investors. For a given state of economy, the uncertainty facing the investor is the sum of the uncertainty in the data and the uncertainty of the investor's assessment of the mean of the expected return. Investor response to macroeconomic uncertainty is shown to depend on the level of information an investor has about the data generating model.

Investors are assumed to update their information from observation of signals. This learning influences the decision on whether to invest. The investor's knowledge makes a particularly large difference when the economy is in a state characterized by greater uncertainty and higher potential expected return. Simulation of the model suggests that in the wake of such a state the total number of investments may increase and will be characterized initially by an abnormally high percentage of investments by informed investors. The model implies that if subjective uncertainties are time varying across investors the aggregate response of investment to change in macroeconomic variables during uncertainty will also vary.

We test the theory with firm-level data on FDI to Korea during the unusual behavior of the Korean won/US dollar exchange rate at the time of the Asian financial crisis. In negative-binomial regressions, we find that the FDI count for investors with more information indicated by experience and size of FDI is more responsive to changes in macroeconomic uncertainty measured by volatility in the exchange rates whereas that of 
FDI count for uninformed investors is not. In the binomial logit regressions, controlling directly for size of FDI and host firm affiliation, we find that FDI by investors with experience is significantly more likely given volatility in the exchange rate than is FDI by other investors. The empirical results are consistent with the implications of the model about timing of investment in that in response to macroeconomic uncertainty, investors relatively better informed about the parameters of the model have a lower threshold for investment than other investors. 


\section{References}

Abel, Andrew B., Dixit Avinash K., Eberly Janice C. and Robert S. Pindyck (1996). Options, the Value of Capital, and Investment. Quarterly Journal of Economics, 111, 753-777.

Aguiar, Mark and Gita Gopinath (2005). Fire-Sale Foreign Direct Investment and Liquidity Crises. Review of Economics and Statistics, 87, 439-452.

Albuquerque, R. (2003). The Composition of International Capital Flows: Risk Sharing through Foreign Direct Investment. Journal of International Economics, 61, 353-383.

Bertola, Guiseppe, and Ricardo Caballero (1994). Irreversibility and Aggregate Investment. Review of Economic Studies, 61, 223-246.

Blonigen, Bruce A. (1997). Firm-Specific Assets and the Link between Exchange Rates and Foreign Direct Investment. American Economic Review, 87, 447-65.

Blonigen, Bruce A. (2005). A Review of the Empirical Literature on FDI Determinants. NBER Working Paper, 11, 299.

Bloom , Nick, Stephen Bond and John Van Reenen (2007). Uncertainty and Investment Dynamics. Review of Economic Studies, 74, 391-415.

Borensztein, Eduardo and Jong-Wha Lee (2002). Financial Crisis and Credit Crunch in Korea: Evidence from Firm Level Data. Journal of Monetary Economics, 49, 853-875.

Campa, Jose Manuel (1993). Entry by Foreign Firms in the United States under Exchange Rate Uncertainty. Review of Economics and Statistics, 75 (4), 614-622.

Caves, Richard (1971). International Corporations: The Industrial Economics of Foreign Investment. Economica, 38, 1-27.

Cushman, David O. (1985). Real Exchange Rate Risk, Expectations, and the Level of Direct Investment. Review of Economics and Statistics, 67 (2), 297-308.

Dixit, Avinash K. (1989). Entry and Exit Decisions under Uncertainty. Journal of Political Economy, 97, 620-38.

Dixit, Avinash K. and Pindyck, Robert S. (1994). Investment under Uncertainty. Princeton, New Jersey: Princeton University Press.

Easley, D. and N. M. Kiefer (1988). Controlling a Stochastic Process with Unknown Parameters. Econometrica, 56, 1045-1064.

Froot, Kenneth A. and Stein, Jeremy (1991). Exchange Rates and Foreign Direct Investment: An Imperfect Capital Market Approach. Quarterly Journal of Economics, 106, 1191-1217.

Goldberg, Linda S. and Charles D. Kolstad (1995). Foreign Direct Investment, Exchange Rate Variability and Demand Uncertainty. International Economic Review, 36 (4), 855-873.

Gryglewicz, S., Huisman, K. J. M., Kort, P. M. (2008). Finite Project Life and Uncertainty Effects on Investment. Journal of Economic Dynamics and Control, 32 (7), 2191-2213.

Gutierrez, O. (2007). Devaluating Projects and the Investment-Uncertainty Relationship. Journal of Economic Dynamics and Control, 31 (12), 3881-3888.

Hausman, Jerry A, B. Hall, and Z. Griliches (1984). Econometric Models for Count Data with an Application to the Patents-R\&D Relationship. Econometrica, 52, 909-938. 
Hausmann, Ricardo, and Eduardo Fernández-Arias (2001). Foreign Direct Investment: Good Cholesterol? In Foreign Direct Investment Versus Other Flows to Latin America, edited by Jorge Braga de Macedo and Enrique V. Iglesias. Paris: Inter-American Development Bank and OECD.

Jovanovic, Boyan (1979). Job Matching and the Theory of Turnover. Journal of Political Economy, 87, 972-90.

Kindleberger, C.P. (1969). American Business Abroad: Six Lectures on Direct Investment. New Haven: Yale University Press.

Kiyota, Kozo and Shujiro Urata (2004). Exchange Rate, Exchange Rate Volatility and Foreign Direct Investment. World Economy, 27, 1501-1536.

Klein, Michael W. and Eric Rosengren (1994). The Real Exchange Rate and Foreign Direct Investment in the United States. Journal of International Economics, 36, 373-389.

Krugman, Paul (1998). Fire Sale FDI. MIT working paper.

Lipsey, Robert E. (2000). Interpreting Developed Countries' Foreign Direct Investment. NBER Working Paper, 7810.

Lipsey, Robert E. (2001). Foreign Direct Investment in Three Financial Crises. NBER Working Paper, 8084.

McDonald, Robert L. and Daniel Siegel (1986). The Value of Waiting to Invest. Quarterly Journal of Economics, 101, 707-27.

Mody, Ashoka, Assaf Razin, and Efraim Sadka (2002). The Role of Information in Driving FDI: Theory and Evidence. NBER Working Paper, 9255.

Prescott, Edward C. and Robert M. Townsend (1980). Equilibrium Under Uncertainty: Multiagent Statistical Decision Theory. In Bayesian Analysis in economics and Statistics, edited by Arnold Zellner, 167-194.

Rauch, James E. and Vitor Trindade (2003). Information, International Substitutability, and Globalization. American Economic Review, 93, 775-91.

Razin, Assaf and Efraim Sadka (2003). Gains from FDI Inflows with Incomplete Information. Economics Letters, 78, 71-77.

Wieland, Volker (2000). Monetary Policy, Parameter Uncertainty and Optimal Learning. Journal of Monetary Economics, 46 (1), 199-228.

Wong, K.P. (2007). The Effect of Uncertainty on Investment Timing in a Real Options Model. Journal of Economic Dynamics and Control, 31 (7), 2152-2167. 


\section{Conomics}

The Open-Access, Open-Assessment E-Journal

Please note:

You are most sincerely encouraged to participate in the open assessment of this article. You can do so by either recommending the article or by posting your comments.

Please go to:

www.economics-ejournal.org/economics/journalarticles/2009-41

The Editor 